\title{
Assessing the ability to derive rates of polar middle-atmospheric descent using trace gas measurements from remote sensors
}

\author{
Niall J. Ryan ${ }^{1}$, Douglas E. Kinnison ${ }^{2}$, Rolando R. Garcia ${ }^{2}$, Christoph G. Hoffmann ${ }^{3}$, Mathias Palm ${ }^{1}$, Uwe Raffalski ${ }^{4}$, \\ and Justus Notholt ${ }^{1}$ \\ ${ }^{1}$ Institute of Environmental Physics, University of Bremen, Bremen, 28359, Germany \\ ${ }^{2}$ Atmospheric Chemistry Observations and Modeling Laboratory, National Center for Atmospheric Research, \\ Boulder, Colorado, USA \\ ${ }^{3}$ Institute of Physics, University of Greifswald, Felix-Hausdorff-Str. 6, 17489, Greifswald, Germany \\ ${ }^{4}$ Swedish Institute of Space Physics, Box 812, 98128 Kiruna, Sweden
}

Correspondence: Niall J. Ryan (n_yan@iup.physik.uni-bremen.de)

Received: 15 June 2017 - Discussion started: 21 June 2017

Revised: 27 November 2017 - Accepted: 16 December 2017 - Published: 2 February 2018

\begin{abstract}
We investigate the reliability of using trace gas measurements from remote sensing instruments to infer polar atmospheric descent rates during winter within 46-86 km altitude. Using output from the Specified Dynamics Whole Atmosphere Community Climate Model (SD-WACCM) between 2008 and 2014, tendencies of carbon monoxide (CO) volume mixing ratios (VMRs) are used to assess a common assumption of dominant vertical advection of tracers during polar winter. The results show that dynamical processes other than vertical advection are not negligible, meaning that the transport rates derived from trace gas measurements do not represent the mean descent of the atmosphere. The relative importance of vertical advection is lessened, and exceeded by other processes, during periods directly before and after a sudden stratospheric warming, mainly due to an increase in eddy transport. It was also found that $\mathrm{CO}$ chemistry cannot be ignored in the mesosphere due to the night-time layer of $\mathrm{OH}$ at approximately $80 \mathrm{~km}$ altitude. $\mathrm{CO}$ VMR profiles from the Kiruna Microwave Radiometer and the Microwave Limb Sounder were compared to SD-WACCM output, and show good agreement on daily and seasonal timescales. SDWACCM CO profiles are combined with the CO tendencies to estimate errors involved in calculating the mean descent of the atmosphere from remote sensing measurements. The results indicate errors on the same scale as the calculated descent rates, and that the method is prone to a misinterpretation of the direction of air motion. The "true" rate of atmospheric descent is seen to be masked by processes, other than
\end{abstract}

vertical advection, that affect $\mathrm{CO}$. We suggest an alternative definition of the rate calculated using remote sensing measurements: not as the mean descent of the atmosphere, but as an effective rate of vertical transport for the trace gas under observation.

\section{Introduction}

The rate of the descent of air above the poles during winter has been an area of interest for some time because it influences the transport of trace gases from the thermosphere to the middle atmosphere (mesosphere and stratosphere; e.g. Plumb et al., 2002; Engel et al., 2006; Smith et al., 2011; Manney et al., 2009). This vertical branch of the meridional circulation can transport gases with high thermospheric volume mixing ratios (VMRs), and change the composition of the middle atmosphere (e.g. Solomon et al., 1985; Allen et al., 2000; Hauchecorne et al., 2007; Smith et al., 2011; Garcia et al., 2014; Manney et al., 2009; 2015; Funke et al., 2014a, b, 2017). The downward transport of nitrogen oxide (NO), produced at around $110 \mathrm{~km}$ through energetic particle precipitation (EPP) events (e.g. Barth and Bailey, 2004; Randall et al., 2005, 2007, 2015), garners particular attention because $\mathrm{NO}_{x}\left(\mathrm{NO}+\mathrm{NO}_{2}\right)$ catalytically destroys ozone in the stratosphere. Periods of strong atmospheric descent are known to coincide with the timing of sudden stratospheric warmings (SSWs; e.g. Manney et al., 2003, 2009; Jackman et al., 
2009; Siskind et al., 2010; Holt et al., 2013). Elevated VMRs of carbon monoxide $(\mathrm{CO})$ and $\mathrm{NO}_{x}$ have been observed to linger in the middle atmosphere when there is an exceptionally strong polar vortex after a strong SSW, helping to confine descending air at the pole (Randall et al., 2006). Randall et al. (2009) suggest that, in these cases, VMRs of EPPproduced $\mathrm{NO}_{x}$ are controlled more by mesosphere and lower thermosphere (MLT) descent rates than by the structure of the vortex. Siskind et al. (2016) found that due to downward transport of methane $\left(\mathrm{CH}_{4}\right)$ in years with strong, uninterrupted mesospheric descent, summertime upper stratospheric chlorine monoxide $(\mathrm{ClO})$ is about $50 \%$ greater than in years with strong horizontal transport.

A direct measurement of the mean vertical motion of air in the middle atmosphere is currently not possible because of the small velocities, and so an analysis of changes in measured tracer (relatively long-lived trace gas) VMRs offers a means to indirectly observe the vertical motion. This technique has often been used in combination with ozone measurements in the stratosphere to separate chemical and dynamical influences when determining ozone depletion (e.g. Proffit et al., 1990, 1993; Müller et al., 1996, 2003; Salawitch et al., 2002; Rösevall et al., 2007). Another indirect determination can be made using the diabatic circulation approach (e.g. Dunkerton, 1978; Solomon et al., 1986; Medvedev and Fomichev, 1994) but this method is not discussed further here. The chemical lifetime of $\mathrm{CO}$ during polar night and the strong vertical gradient in its VMR make it a good tracer (Solomon et al., 1985; Allen et al., 1999; Lee et al., 2011). Water vapour $\left(\mathrm{H}_{2} \mathrm{O}\right)$ is used to infer vertical motion (e.g. Straub et al., 2012) but a varying vertical gradient limits the altitudes at which it can be used (Lee et al., 2011). Nassar et al. (2005) used nitrous oxide $\left(\mathrm{N}_{2} \mathrm{O}\right), \mathrm{CH}_{4}$, and $\mathrm{H}_{2} \mathrm{O}$ to infer rates of vertical motion in the upper stratosphere and lower mesosphere, and Bailey et al. (2014) used a combination of $\mathrm{NO}, \mathrm{H}_{2} \mathrm{O}$, and $\mathrm{CH}_{4}$ to derive profiles of vertical motion in the middle atmosphere. A partial list of studies that have used tracers to calculate rates of vertical motion is given in Table 1, similar to Hoffmann (2012) for studies using $\mathrm{CO}$. The tracers used and the determined rates are also listed, along with the terminology used to describe the motion. The descent rates range from -100 to $-1200 \mathrm{~m} \mathrm{day}^{-1}$ and show much variability, which can be expected as the studies were performed for different years and/or different times of the year, and at different locations (with the minus sign indicating descent rather than ascent). The altitude range over which the rates were determined, and whether averaging was performed, is also shown in Table 1 . It is important to note that an average over altitude can mask the higher descent rates that are found in the mesosphere. For example, Straub et al. (2012) show a descent rate of $-325 \mathrm{~m} \mathrm{day}^{-1}$ from averaged modelled wind profiles, between $0.6(\sim 52 \mathrm{~km})$ and $0.06 \mathrm{hPa}(\sim 68 \mathrm{~km})$, whereas the individual wind profiles often show descent rates larger than $-1000 \mathrm{~m} \mathrm{day}^{-1}$ at $0.06 \mathrm{hPa}$.
A general assumption made in the derivations of the rates is that the observed change in a tracer VMR over time is caused by vertical advection. The assumption draws from the fact that the polar vortex edge acts as a barrier to lowerlatitude air and hinders horizontal mixing of air masses between the inside and outside of the vortex (Schoeberl et al., 1992; Manney et al., 1994), but limited mixing still occurs and defining the edges of the polar vortex is not straightforward (Manney et al., 1994, 1997; Harvey et al., 2009, 2015). During the formation/breakdown of the polar vortex at the beginning/end of winter, the transport barrier is weaker and the location of the vortex edge becomes much less welldefined (Manney et al., 1997), making it more difficult to identify inner-vortex air masses. This is also true for SSW events where the vortex is weakened, or breaks down and reforms, allowing increased mixing (Manney et al., 2009, 2015). When the vortex is well established, the edge definitions that rely on wind fields (such as scaled potential vorticity (e.g. Manney et al., 1994, 2007, 2011; Jin et al., 2006) become less reliable in the mesosphere where wind observations are uncommon and reanalysis winds are known to be fallible (Manney et al., 2008a, b; Rienecker et al., 2011).

The aim of this study is to assess the limits of the above assumption when using tracer measurements from remote sounders to derive rates of vertical motion in the middle atmosphere. Measurements alone do not provide enough information to enable separation of the contributions to changes in tracer VMRs, and so an atmospheric model must be employed. The specified dynamics version of the Whole Atmosphere Community Climate Model (SD-WACCM) is used to determine the relative contributions to changes in CO VMRs during polar winter. The results are combined with daily average modelled $\mathrm{CO}$ to estimate the error associated with descent rates calculated assuming pure vertical advection of the tracer. Three commonly used representations of the data are assessed: a local area above a specific location (Kiruna, $67.8^{\circ} \mathrm{N}, 20.4^{\circ} \mathrm{E}$, in this case), a zonal mean at a certain latitude $\left(80^{\circ} \mathrm{N}\right.$ is used as an example), and a polar mean (60$90^{\circ} \mathrm{N}$ ). The winters of 2008/2009 and 2010/2011 are used in the study as an example of a winter with a strong SSW and a winter with a relatively stable vortex, respectively. The rate calculations were also performed using $\mathrm{CO}$ measurements from the Kiruna Microwave Radiometer (KIMRA) and the Microwave Limb Sounder (MLS) (not shown), and the results lead to the same conclusion. This was expected due to the level of agreement found in a comparison of the modelled and measured $\mathrm{CO}$ (Sect. 2.4).

Section 2 outlines the instruments and the model used in this study as well as their datasets. A brief comparison of the three $\mathrm{CO}$ datasets is provided to assess how well the model represents observations of the atmosphere. Section 3 investigates the trajectories of air parcels arriving in the Arctic during winter, and the evolution of the tendencies of CO VMRs in the Arctic middle atmosphere due to each component of the continuity equation. Section 4 shows the rates of verti- 
Table 1. A partial list of studies that used atmospheric tracers to derive rates of vertical air motion in the atmosphere.

\begin{tabular}{|c|c|c|c|c|c|c|c|}
\hline Reference & Tracer & Location & Instrument & $\begin{array}{l}\text { Rate of vertical motion } \\
\qquad\left(\mathrm{m} \mathrm{day}^{-1}\right)\end{array}$ & $\begin{array}{r}\text { Approximate } \\
\text { altitude(s) }\end{array}$ & Time of year & Terminology \\
\hline Allen at al. (2000) & $\mathrm{CO}$ & Antarctica & satellite & $\begin{array}{l}-250 \text { at } 60^{\circ} \mathrm{S} \\
-300 \text { at } 80^{\circ} \mathrm{S}\end{array}$ & $\begin{array}{r}30-50 \mathrm{~km} \\
\text { average }\end{array}$ & $\begin{array}{l}\text { Apr/May average, } \\
1992\end{array}$ & atmospheric descent \\
\hline Forkman et al. (2005) & $\mathrm{CO}$ & $\mathrm{NH}$ mid-latitudes & ground-based & +250 to +450 & $60-95 \mathrm{~km}$ & Spring, 2002 & mesospheric circulation \\
\hline Forkman et al. (2005) & $\mathrm{CO}$ & NH mid-latitudes & ground-based & 0 to -300 & $60-95 \mathrm{~km}$ & Autumn, 2002 & mesospheric circulation \\
\hline Nassar et al. (2005) & $\mathrm{CH}_{4}, \mathrm{H}_{2} \mathrm{O}$ & Arctic & satellite & -150 & upper stratosphere & Feb/Mar, 2004 & atmospheric descent \\
\hline Nassar et al. (2005) & $\mathrm{CH}_{4}, \mathrm{H}_{2} \mathrm{O}$ & Arctic & satellite & -175 & lower mesosphere & $\begin{array}{l}\text { Oct } 2003 \text { to Feb } 2004 \\
\text { average }\end{array}$ & atmospheric descent \\
\hline Hauchercorne et al. (2007) & $\mathrm{NO}_{2}$ & Arctic & satellite & $\begin{array}{r}\text { from }-600 \text { in Jan, } \\
\text { to }-200 \text { in Mar }\end{array}$ & $45-70 \mathrm{~km}$ & $20 \mathrm{Jan}$ to $10 \mathrm{Mar}, 2004$ & descent of $\mathrm{NO}_{2}$ layer \\
\hline Funke et al. (2009) & $\mathrm{CO}$ & Arctic & satellite & -350 to 400 & $50-70 \mathrm{~km}$ & Sep/Oct, 2003 & polar descent \\
\hline Funke et al. (2009) & $\mathrm{CO}$ & Arctic & satellite & -200 to -300 & $40-70 \mathrm{~km}$ & Nov/Dec, 2003 & polar descent \\
\hline Funke et al. (2009) & $\mathrm{CO}$ & Arctic & satellite & -1200 & mesosphere & after SSW, 2004 & polar descent \\
\hline Di Bagio et al. (2010) & $\mathrm{CO}$ & Arctic & ground-based & -200 to -300 & $\begin{array}{r}\text { descent from } \\
58-62 \mathrm{~km}\end{array}$ & after SSW, 2009 & descent of air \\
\hline $\begin{array}{l}\text { Di Bagio et al. (2010), } \\
\text { from Orsolini et al. (2010) }\end{array}$ & $\mathrm{H}_{2} \mathrm{O}$ & Arctic & ground-based & -200 to -300 & $\begin{array}{l}\text { descent from } \\
59 \text { and } 62 \mathrm{~km}\end{array}$ & after SSW, 2009 & descent of air \\
\hline Straub et al. (2012) & $\mathrm{H}_{2} \mathrm{O}$ & Arctic & ground-based & -350 & $52-68 \mathrm{~km}$ average & $\begin{array}{l}5 \text { Feb to } 5 \text { Mar } \\
\text { average, } 2010\end{array}$ & polar descent \\
\hline Straub et al. (2012) & $\mathrm{H}_{2} \mathrm{O}$ & Arctic & satellite & -360 & $52-68 \mathrm{~km}$ average & $\begin{array}{l}\text { Jan/Feb/Mar } \\
\text { average, } 2010\end{array}$ & polar descent \\
\hline Bailey et al. (2014) & $\mathrm{NO}, \mathrm{H}_{2} \mathrm{O}, \mathrm{CH}_{4}$ & Arctic & satellite & up to -1000 & $40-90 \mathrm{~km}$ & after SSW, 2013 & atmospheric descent \\
\hline
\end{tabular}

cal motion calculated using $\mathrm{CO}$ measurements and the above assumption, and estimates how these rates change when accounting for all parts of the continuity equation. Section 5 uses CO VMR tendencies from 2008 to 2014 to assess their relative importance during different months. Section 6 contains a discussion of the results and the limitations of the study, and suggests a different interpretation of the rates derived from tracer measurements. Section 7 provides concluding remarks.

\section{Instruments, model, and data}

\subsection{KIMRA}

KIMRA is a ground-based microwave remote sensor located at the Swedish Institute for Space Physics, Kiruna, Sweden $\left(67.8^{\circ} \mathrm{N}, 20.4^{\circ} \mathrm{E}\right)$. The instrument is a passive remote sensor and radiances from atmospheric $\mathrm{CO}$ are measured at a frequency $230.54 \mathrm{GHz}$. Specific details on the instrument can be found in Raffalski et al. (2002) and Hoffmann et al. (2011). The current CO dataset from KIMRA covers Arctic winters from 2008 to 2015 with gaps corresponding to instrument non-operation and summer periods when CO VMRs in the middle atmosphere are too low to be accurately measured. The average altitude range of the data is $46-86 \mathrm{~km}$ and the vertical resolution is $15-18.5 \mathrm{~km}$, depending on the altitude. Details on the measurement technique and CO inversion scheme are given in Ryan et al. (2017a). The average precision (values can vary from one profile to another) of wintertime KIMRA CO VMRs range from $0.06 \mathrm{ppm}$ at $46 \mathrm{~km}$ altitude to $2.7 \mathrm{ppm}$ at $86 \mathrm{~km}$. The average time resolution of a $\mathrm{CO}$ measurement is around $2 \mathrm{~h}$. KIMRA CO data presented in this work have been averaged to give daily profiles.

\subsection{MLS}

MLS is a microwave remote sensor aboard the Aura satellite, launched in July 2004, and is part of NASA's Earth Observing System. Atmospheric CO is retrieved from radiance measurement made in two bands of the $240 \mathrm{GHz}$ radiometer. A description of the MLS instrument can be found in Waters et al. (2006) and details on the retrieval can be found in Pumphrey et al. (2007) and Livesey et al. (2008). The data used here are version 4.2 (Schwartz et al., 2015), which is described in Livesey et al. (2015). These CO profiles cover a pressure range of $215-0.0046 \mathrm{hPa}$ (approximately $11-86 \mathrm{~km}$ ) and have a maximum (largest) precision of $11 \mathrm{ppm}$ at the highest (in altitude) pressure level. For the data used here, the vertical resolution is between 3.8 and $6.2 \mathrm{~km}$, and the horizontal resolution is between 200 and $250 \mathrm{~km}$. MLS data presented here as above Kiruna are within $\pm 2^{\circ}$ latitude and $\pm 10^{\circ}$ longitude of Kiruna, and have been averaged to produce daily profiles.

\subsection{SD-WACCM}

The Community Earth System Model version 1 (CESM1), Whole Atmosphere Community Climate Model (WACCM), is a coupled chemistry climate model from the Earth's surface to the lower thermosphere (Marsh et al., 2013 and references therein). WACCM is a superset of the Community Atmosphere Model, version 4 (CAM4), and includes all of the physical parameterizations of CAM4 (Neale et al., 2013) and a finite volume dynamical core (Lin, 2004) for the tracer advection. The simulation of WACCM4 used in this study is run with specified dynamics (SD) fields, using meteorological analyses from the National Aeronautics and Space Administration (NASA) Global Modeling and Assimilation Office (GMAO) Modern-Era Retrospective Analysis for Research and Applications (MERRA; Rienecker et al., 2011). 
The chemical component is based on version 3 of the Model for Ozone and Related Chemical Tracers (Kinnison et al., 2007). Garcia et al. (2014) discuss an update to the absorption cross section for $\mathrm{O}_{2}$, which increased modelled $\mathrm{CO}$ mixing ratios in the MLT, bringing them closer to observations.

SD-WACCM constrains the atmosphere towards observations below $50 \mathrm{~km}$ through nudging with data from the above-mentioned analysed meteorological fields. Above $60 \mathrm{~km}$ the atmosphere is fully interactive and between 50 and $60 \mathrm{~km}$ the nudging linearly decreases to zero. Details on the nudging of the temperature and wind fields in the model can be found in Lamarque et al. (2012) and references therein. The model also tends towards observations at altitudes above $60 \mathrm{~km}$ because the zonal-mean mesospheric winds and temperatures at higher altitudes have been shown to be strongly constrained by the stratosphere (Liu et al., 2010; McLandress, 2013), but precise agreement cannot be expected.

For the model runs used in this work, the pressure grid consists of 88 layers from the ground to the thermosphere $(\sim 133 \mathrm{~km})$. The altitude resolution of the grid increases from $\sim 0.1 \mathrm{~km}$ near the surface to $\sim 3.5 \mathrm{~km}$ in thermosphere. The horizontal resolution is $1.9^{\circ} \times 2.5^{\circ}$ in latitude and longitude. Model output of daily averages from 2008 to 2014 are used for this study.

\subsection{CO VMR comparison}

Figure 1 plots the CO VMRs from KIMRA, MLS, and SDWACCM above Kiruna for 2008 through 2014. The aim of a comparison is to see whether the datasets capture the same variability in middle-atmospheric $\mathrm{CO}$. The VMRs are plotted at five altitudes between 46 and $86 \mathrm{~km}$. This is the average altitude range of KIMRA CO data and reaches the upper altitude limit of MLS CO data. The MLS and SDWACCM VMRs are also plotted after the profiles have been smoothed with the KIMRA averaging kernels (Rodgers and Connor, 2003). This method allows a meaningful comparison of datasets that have significantly different vertical resolutions. A more comprehensive comparison of the current KIMRA and MLS data is given in Ryan et al. (2017a). SDWACCM data are here bilinearly interpolated to the location of Kiruna, but a significant change in the results is not found when simply using the model coordinate grid point closest to Kiruna. The three $\mathrm{CO}$ datasets show agreement on seasonal and daily timescales. Agreement between the model and instruments on such timescales highlights the power of SDWACCM as a tool for investigating trends as well as temporally short events in the atmosphere. A systematic difference is evident between MLS and SD-WACCM during the times of year when CO VMRs are rapidly increasing or decreasing, with SD-WACCM showing larger values of CO. The difference is most pronounced at higher altitudes and is predominantly during August/September and April/May. Table 2 lists the correlation and regression coefficients calculated for each data pairing. Regression coefficients are calculated account- ing for errors in the abscissa and ordinate variables (York et al., 2004), with a $15 \%$ error assumed for SD-WACCM CO VMRs. Correlations between KIMRA and smoothed MLS, and KIMRA and smoothed SD-WACCM, are $\geq 0.86$ at all altitudes, and MLS and SD-WACCM correlations are $\geq 0.88$. MLS and SD-WACCM were compared at other polar locations (not shown here) and display similar agreement. The values are similar to those found for earlier versions of the model and data (Hoffmann et al., 2012), with differences mainly due to updates to the modelled CO (Garcia et al., 2014) and the data products (Livesey et al., 2015; Ryan et al., 2017a).

\section{Contributions to the $\mathrm{CO}$ continuity equation}

\subsection{The TEM continuity equation}

The mass transport of the residual mean meridional circulation is well represented by the transformed Eulerian mean (TEM) formulation (Andrews and McIntyre, 1976), and is covered in detail in Andrews et al. (1987). The TEM circulation in the solstice seasons is dominated by flow from the summer to the winter pole, accompanied by downward and upward transport above the winter and summer poles, respectively. The TEM zonal-mean tracer continuity equation has been described in various works (e.g. Garcia and Solomon, 1983; Andrews et al., 1987; Brasseur and Solomon, 2005; Monier and Weare, 2005; Smith et al., 2011):

$$
\begin{aligned}
& \frac{\partial \bar{\chi}}{\partial t}=-\overline{w^{*}} \frac{\partial \bar{\chi}}{\partial z}-\overline{v^{*}} \frac{\partial \bar{\chi}}{\partial y}+\bar{S}+\overline{X_{\mathrm{mol}}}+\frac{1}{\rho_{0}} \nabla \cdot M \\
& +\overline{\frac{1}{\rho_{0}} \frac{\partial}{\partial z}\left(\rho_{0} K_{z z} \frac{\partial \chi}{\partial z}\right)}
\end{aligned}
$$

where $\chi$ is the CO VMR, $\overline{w^{*}}$ is the vertical component of the residual mean meridional circulation, and $\overline{v^{*}}$, is the horizontal component. $\bar{S}$ is the zonal-mean net chemical production of $\mathrm{CO}$ and $\overline{X_{\mathrm{mol}}}$ is the zonal-mean molecular diffusion of CO. $\nabla \cdot M$ is the divergence of the resolved eddy flux vector and describes the eddy transport of $\mathrm{CO}$, with $\rho_{0}$ as the basic density. $K_{z z}$ is the diffusion coefficient due to unresolved small-scale gravity wave breaking, and the last component of Eq. (1) represents the transport of $\mathrm{CO}$ due to parameterized eddy flux divergence (from gravity waves). The righthand-side (RHS) terms of Eq. (1) are calculated using daily averaged output from SD-WACCM and details on the exact equations can be found in Andrews et al. (1987). The value of $K_{z z}$ calculated with SD-WACCM depends, among other things, upon the Prandtl number (or more properly, the "turbulent Prandtl number"), which describes the ratio of momentum flux to heat flux. The Prandtl number is a property of the process whereby gravity waves dissipate when they "break" (see e.g. Fritts and Dunkerton, 1985, for more details). The Prandtl number is 2 for the model runs in this 
Table 2. "Correlation coefficient, regression coefficient \pm error" for comparisons of daily CO VMRs from KIMRA, MLS, and SD-WACCM above Kiruna for 2008 through 2014. The abscissa variable is the first-named of each instrument pairing. A regression coefficient $>1$ ( $<1)$ indicates a larger (smaller) range in the abscissa variable. Figure 1 shows the time series of each CO VMR dataset. See Sect. 2.4 for details.

\begin{tabular}{rrrrrrr}
\hline & KIMRA-MLS & $\begin{array}{r}\text { KIMRA- } \\
\text { MLSsmooth }\end{array}$ & KIMRA-WACCM & $\begin{array}{r}\text { KIMRA- } \\
\text { WACCMsmooth }\end{array}$ & $\begin{array}{r}\text { MLS-WACCM } \\
\text { WACCMsmooth }\end{array}$ & $\begin{array}{c}\text { MLSsmooth- } \\
\text { WACC1 }\end{array}$ \\
\hline $86 \mathrm{~km}$ & $0.87,0.95 \pm 0.03$ & $0.93,1.26 \pm 0.05$ & $0.81,1.05 \pm 0.01$ & $0.86,1.25 \pm 0.01$ & $0.90,1.00 \pm 0.02$ & $0.89,0.93 \pm 0.05$ \\
$76 \mathrm{~km}$ & $0.90,1.46 \pm 0.03$ & $0.94,1.27 \pm 0.03$ & $0.89,1.18 \pm 0.01$ & $0.89,1.26 \pm 0.01$ & $0.91,0.78 \pm 0.01$ & $0.87,0.78 \pm 0.02$ \\
$66 \mathrm{~km}$ & $0.90,1.27 \pm 0.02$ & $0.95,1.36 \pm 0.03$ & $0.85,1.20 \pm 0.01$ & $0.90,1.26 \pm 0.01$ & $0.90,0.83 \pm 0.01$ & $0.85,0.72 \pm 0.01$ \\
$56 \mathrm{~km}$ & $0.91,1.01 \pm 0.02$ & $0.95,1.20 \pm 0.02$ & $0.88,0.95 \pm 0.01$ & $0.90,1.00 \pm 0.01$ & $0.89,0.86 \pm 0.01$ & $0.86,0.70 \pm 0.01$ \\
$46 \mathrm{~km}$ & $0.88,0.38 \pm 0.01$ & $0.91,1.23 \pm 0.04$ & $0.89,0.30 \pm 0.01$ & $0.90,0.95 \pm 0.02$ & $0.88,0.86 \pm 0.01$ & $0.83,0.63 \pm 0.01$ \\
\hline
\end{tabular}

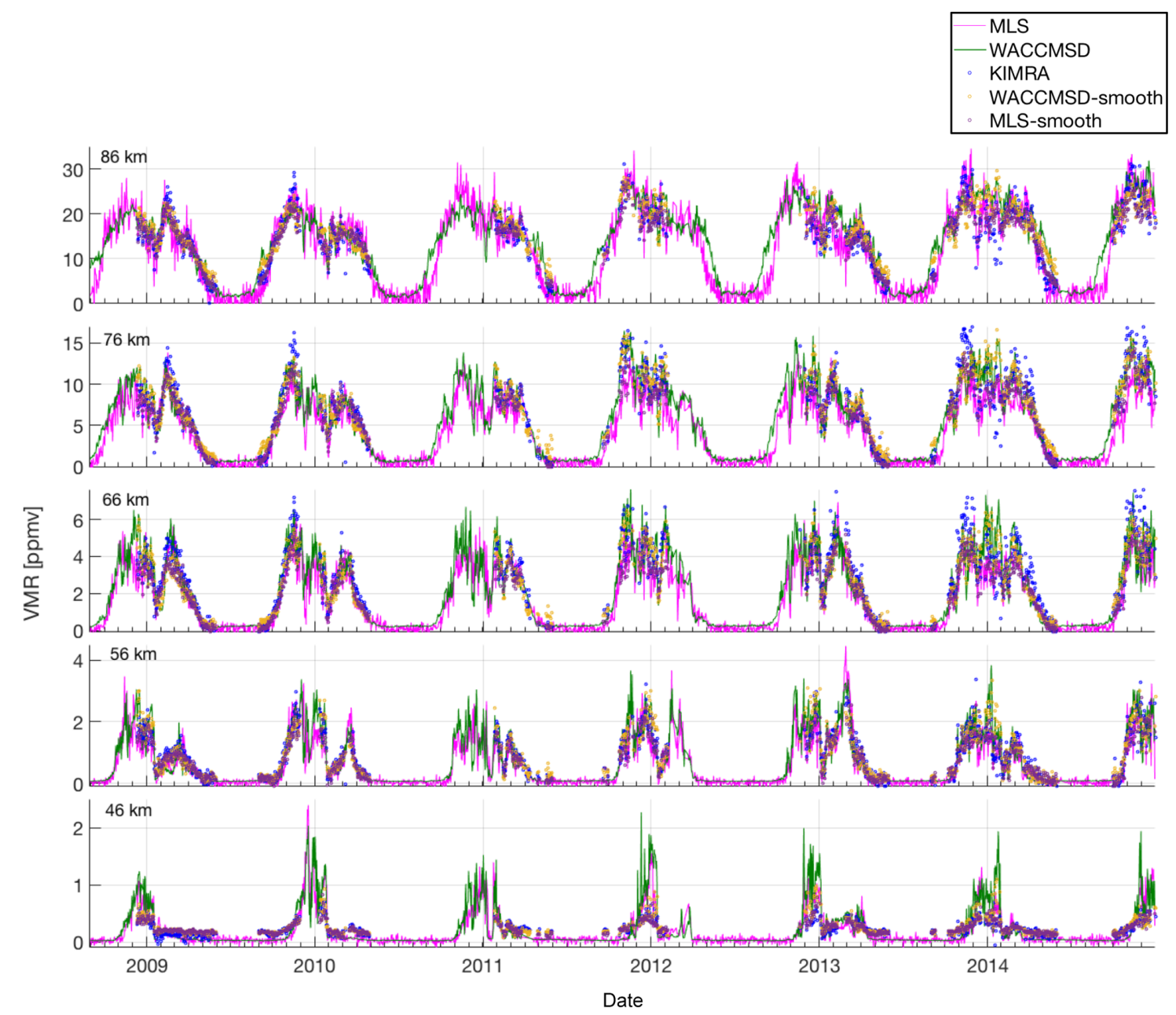

Figure 1. Comparisons of daily CO VMRs from KIMRA, MLS, and SD-WACCM above Kiruna for 2008 through 2014. Values are displayed at 46, 56, 66, 76, and $86 \mathrm{~km}$ altitude. Correlation and regression coefficients for the datasets are given in Table 2. See Sect. 2.4 for details.

work (see Sect. 6) and is used in SD-WACCM to parameterize gravity wave breaking (Garcia et al., 2007). Finite differences in Eq. (1) are calculated as centred differences except at the boundaries of grids, where forward and backward differences are used.
The terms of Eq. (1) are renamed here as

$\frac{\partial \bar{\chi}}{\partial t}=\operatorname{adv} \_w^{*}+\operatorname{adv} \_v^{*}+\operatorname{chem}+\mathrm{Xmol}+\mathrm{Xedd}+\mathrm{Xk}_{z z}$

to simply express the tendencies of $\mathrm{CO}$ in the continuity equation. The change in zonal-mean CO VMR with time is a sum of the contributions from (following the RHS of Eq. 2): 
vertical advection, horizontal advection, net chemical production, molecular diffusion, eddy transport, and unresolved eddy transport, which, for present purposes, is due to gravity waves.

\subsection{Trajectories during Arctic winter}

As a first step to examine the assumption of purely vertical tracer advection, the back-trajectories of air parcels during two Arctic winters are plotted in Fig. 2. The parcels arrive at five altitudes between 46 and $86 \mathrm{~km}$ and at two locations, 67 and $80^{\circ} \mathrm{N}$. They are advected, from these locations, backwards in time over 60 days, in $4 \mathrm{~h}$ steps, using $\overline{w^{*}}$ and $\overline{v^{*}}$ from SD-WACCM. The starting date for the trajectory calculations (arrival date of the air parcels) is 28 February, for 2009 and 2011. The winter of 2009 had a major SSW (during which the $10 \mathrm{hPa}$ zonal circulation becomes easterly at $60^{\circ} \mathrm{N}$ ) beginning on 24 January, and 2011 had a relatively stable vortex throughout the winter. The results in Fig. 2 are consistent with similar calculations in Smith et al. (2011) and Straub et al. (2012), for the general shape of the trajectory and in that the parcels do not originate above approximately $100 \mathrm{~km}$. The parcels at $80^{\circ} \mathrm{N}$ arrive from higher altitudes due to a stronger vertical component of the circulation compared to $67^{\circ} \mathrm{N}$. Conversely, the horizontal component of the circulation is stronger at $67^{\circ} \mathrm{N}$ and the parcels arriving there originate from lower latitudes compared to those arriving at $80^{\circ} \mathrm{N}$. The magnitude of the TEM wind is larger for the higher altitudes, as is also shown in Smith et al. (2011), and the air parcels that arrive above $66 \mathrm{~km}$ altitude originate in the summer hemisphere. The parcels that arrive below this altitude, which could be considered as part of the Brewer-Dobson circulation (Brewer, 1949), originate at latitudes closer to the equator. A clear reversal of the trajectory around the time of the SSW can be seen for the air parcel arriving at $56 \mathrm{~km}$ altitude, $80^{\circ} \mathrm{N}$, because of temporary changes in the direction of $\overline{w^{*}}$ and $\overline{v^{*}}$. These changes cause the air parcel to reverse direction before starting to descend again. It is evident from Fig. 2 that the circulations at the pole have varying degrees of vertical and horizontal components.

\subsection{Tendencies of $\mathrm{CO}$ during Arctic winter}

Figures 3, 4, and 5 plot the wintertime tendencies of $\mathrm{CO}$ (RHS of Eq. 2) for 2008/2009 and 2010/2011, for the three scenarios of $67,80^{\circ} \mathrm{N}$, and a north polar average $\left(60-90^{\circ} \mathrm{N}\right)$, respectively. The zonal mean tendencies are plotted as an 11day running mean. Note that the labelled contours may be differently spaced in each panel, to match the range of values for individual tendencies. In the context of a point measurement at Kiruna, a full rotation of the vortex is of the order of 10 days (assuming a zonal wind speed of $20 \mathrm{~m} \mathrm{~s}^{-1}$ at $67^{\circ} \mathrm{N}$ ). Relevant comments on the results are provided here but an in-depth analysis is not made as it is not the focus of the study. Molecular diffusion (Xmol) generally causes negligi-
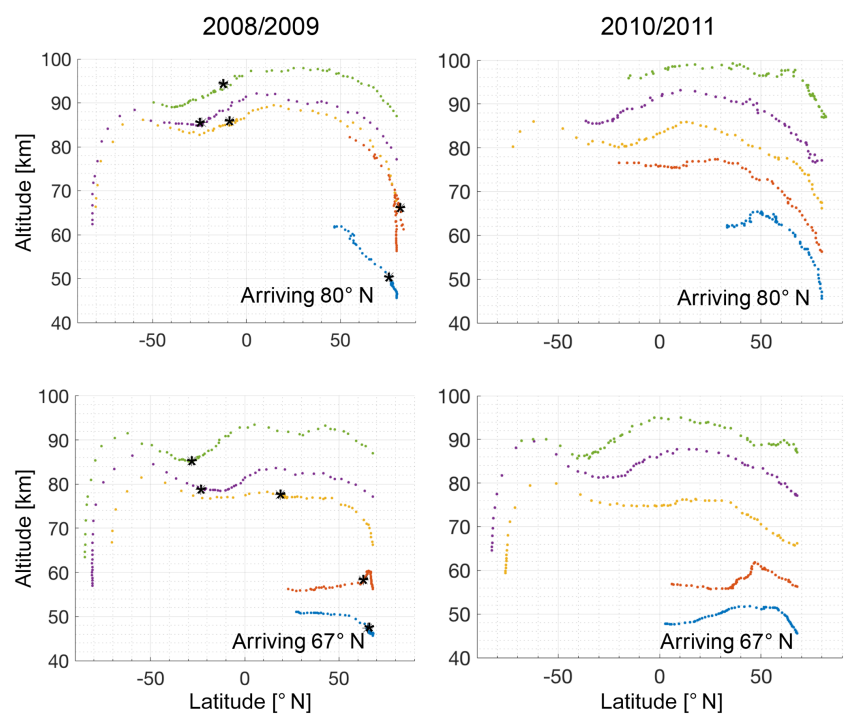

Figure 2. Trajectories of air parcels advected backwards 60 days in time from 28 February 2009 and 2011, by the TEM circulation using SD-WACCM. Trajectories are calculated for air parcels arriving at 67 and $80^{\circ} \mathrm{N}$, at $46,56,66,76$, and $86 \mathrm{~km}$ altitude and locations are plotted at midnight each day. Parcel positions on 28 January 2009 (start date of an SSW) are indicated with a black asterisk. See Sect. 3 for more details.

ble changes in $\mathrm{CO}$, compared to other process, below approximately $83 \mathrm{~km}$, and shows little variation between different scenarios and winters. Above that, the magnitudes increase quickly, with tendencies $<-0.1 \mathrm{ppm} \mathrm{day}^{-1}$ in the altitude range shown here. Unresolved eddy transport $\left(\mathrm{Xk}_{z z}\right)$ is also negligible below approximately $75 \mathrm{~km}$, but can show tendencies $<-0.2$ ppm day $^{-1}$ above that altitude for short times (order of a week). Significant variation is seen for the different winters. Both processes tend to cause a decrease in $\mathrm{CO}$ VMRs throughout the winter in the upper mesosphere, agreeing with results of Smith et al. (2011). For comparison, vertical advection $\left(\operatorname{adv}_{-} w^{*}\right)$ at these altitudes shows positive tendencies ranging from $<0.2$ to $>1.6 \mathrm{ppm} \mathrm{day}^{-1}$. Changes in $\mathrm{CO}$ due to chemistry (chem) are small below approximately $70 \mathrm{~km}$, but each scenario and year shows a sustained sink for $\mathrm{CO}$ during the winter in a layer at around $80 \mathrm{~km}$ altitude. The layer coincides with the location of a night-time layer of hydroxyl $(\mathrm{OH})$ around $82 \mathrm{~km}$ altitude (Brinksma et al., 1998; Pickett et al., 2006; Damiani et al., 2010). OH is known as the dominant chemical sink for middle-atmospheric $\mathrm{CO}$ (Solomon et al, 1985). chem tendencies are stronger at $80^{\circ} \mathrm{N}$ compared to $67^{\circ} \mathrm{N}$, with magnitudes reaching more than $0.3 \mathrm{ppm} \mathrm{day}^{-1}$ in November and December 2010, ranging from approximately 10 to $50 \%$ of $a_{0} \_w^{*}$ over that time. The results suggest that $\mathrm{CO}$ chemistry cannot be ignored in the mesosphere during winter. Tendencies due to resolved eddy diffusion (Xedd) show the most variation between positive and negative values, mainly at $67^{\circ} \mathrm{N}$ because of prox- 
$67.8^{\circ} \mathrm{N}$
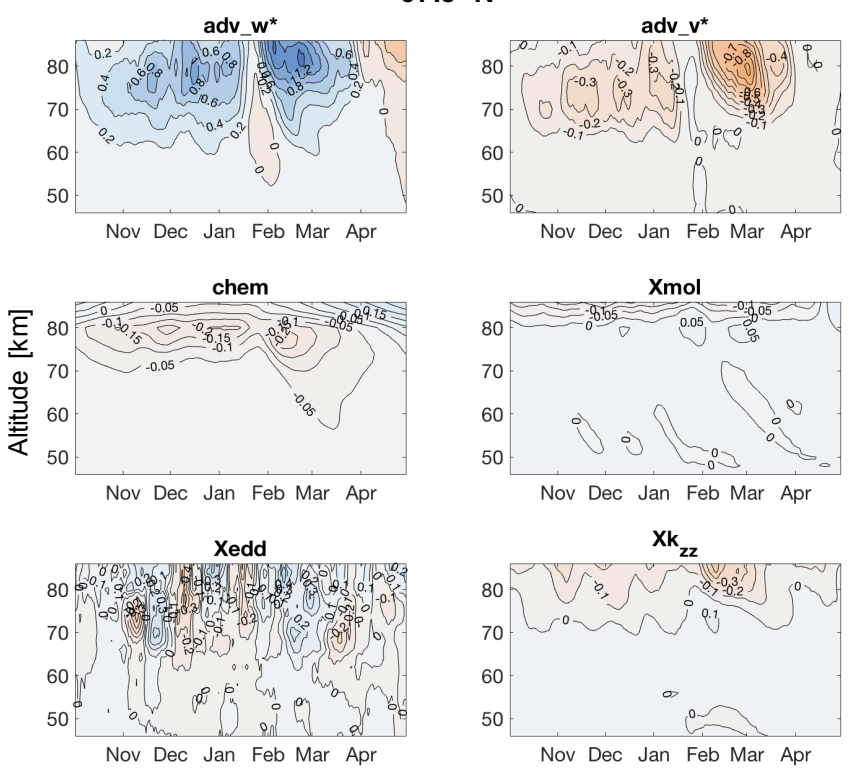

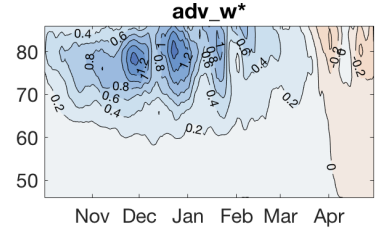

$67.8^{\circ} \mathrm{N}$
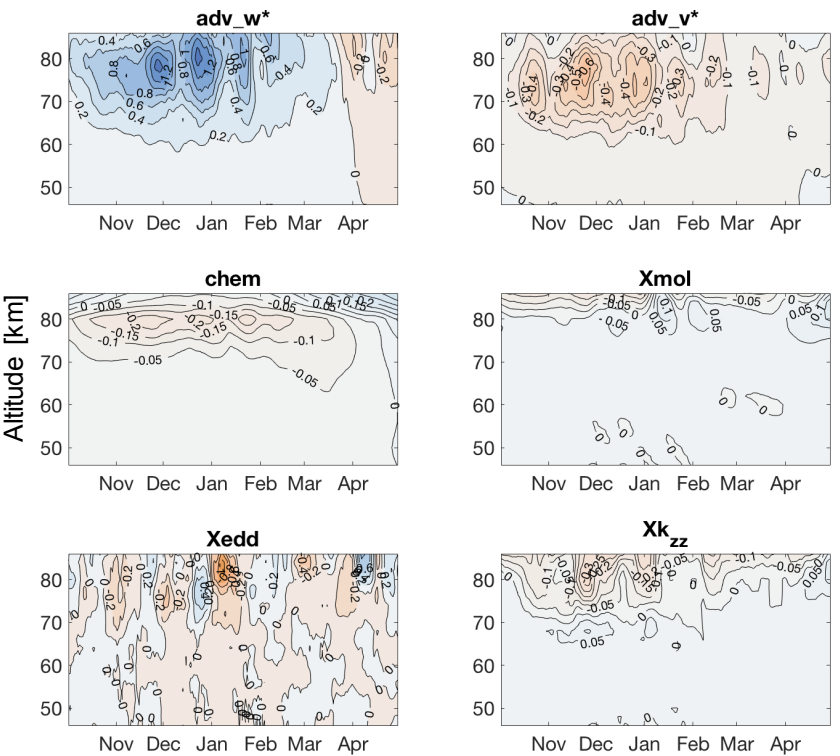

$\underline{2010 / 2011}$

Figure 3. 11-day running mean tendencies of CO (in ppmv day ${ }^{-1}$ ), calculated using daily averaged SD-WACCM output. Tendencies shown are for $67.8^{\circ} \mathrm{N}$ for the winters of 2008/2009 and 2010/2011. See Sect. 3.1 for a description of the tendencies, which are represented in the TEM continuity equation. Note that the labelled contours may be differently spaced in each panel, to match the range of values for individual tendencies.

imity to the edge of the polar vortex. The north polar average shows that Xedd generally reduces CO VMRs during the winter and, above $\sim 70 \mathrm{~km}$, has magnitudes greater than $25 \%$ of adv_ $w^{*}$ for timescales of a week. The largest tendency in $\mathrm{CO}$ is from adv_ $w^{*}$, and causes an almost constant increase in CO VMRs throughout the winter, before reversing when the TEM vertical wind changes direction in spring (visible in all adv_ $w^{*}$ plots). The increase is due to the downward motion of air and the positive gradient of CO VMR with altitude. The tendency is stronger at $80^{\circ} \mathrm{N}$ compared to $67^{\circ} \mathrm{N}$ due to a stronger vertical component of the residual circulation at the higher latitude (Smith et al., 2011, and see Fig. 2). A signature of the major SSW in 2009 can be seen in the adv_ $w^{*}$ tendency for that year, with a decrease and eventual change to a negative tendency. A negative tendency generally indicates ascent of air at this time. For some time directly afterwards, the tendency has a stronger positive magnitude than before. This agrees with observations of stronger vertical motion above the pole after a SSW (see references in Table 1). There is also a brief change to a negative adv $\_w^{*}$ at $80^{\circ} \mathrm{N}$, around $80 \mathrm{~km}$ altitude, in early January 2011 . This coincides with a relatively strong positive value for Xedd at the same time and location, indicating strong wave activity. The $\mathrm{CO}$ tendency from horizontal advection $\left(\mathrm{adv}_{-} v^{*}\right)$ is negative almost everywhere. This is expected, considering the direction of $\overline{v^{*}}$, toward the winter pole, and the low-to-high gradient of $\mathrm{CO}$ from lower to higher latitudes in the winter hemisphere.
The magnitude of the tendency decreases in spring in each scenario and year. but a change of sign is not obvious by the end of April. The advection tendencies show maximum values around $70-80 \mathrm{~km}$ for two main reasons. The first is the larger magnitude of the TEM circulation, compared to lower altitudes, before there is a turnaround in the direction of the circulation at higher altitudes, at which point the circulation changes from poleward and downward to poleward and upward (e.g. Lieberman et al., 2000; Smith et al., 2011). The turnaround point is at approximately $95 \mathrm{~km}$ in WACCM (Smith et al., 2011). The second is the generally increasing vertical gradient of $\mathrm{CO}$ with altitude (see Eq. 1). At $67^{\circ} \mathrm{N}$, the magnitudes of adv $\_v^{*}$ are roughly half that of $\operatorname{adv} \_w^{*}$, and at $80^{\circ} \mathrm{N}$ they are roughly one-fifth. Considering this observation alone, changes in CO VMRs cannot be attributed solely to vertical advection.

\section{Rates of vertical motion with SD-WACCM CO}

In this section, the rates of vertical motion are calculated, using CO profiles from daily averaged SD-WACCM output, by two methods. The first method assumes that observed changes in CO VMRs are due to vertical advection alone. This is a commonly used method (see Table 1) and involves tracking the altitude of a chosen VMR of CO over time and then performing a linear regression on the data of altitude 
$80^{\circ} \mathrm{N}$

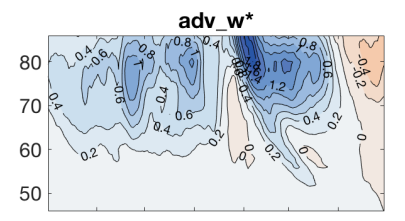

Nov Dec Jan Feb Mar Apr

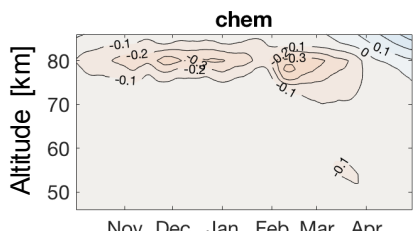

Nov Dec Jan Feb Mar Apr

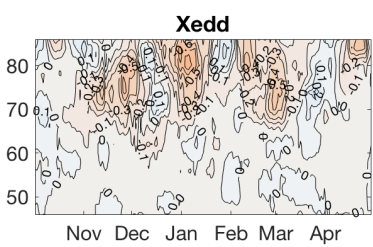

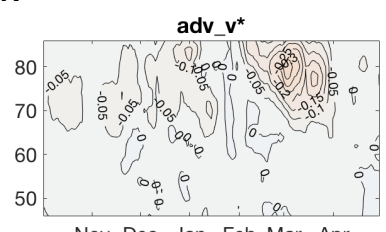

Nov Dec Jan Feb Mar Apr

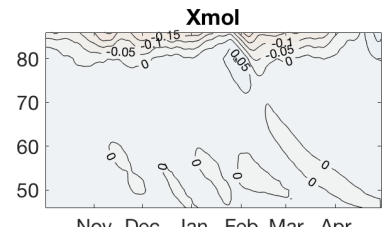

Nov Dec Jan Feb Mar Apr

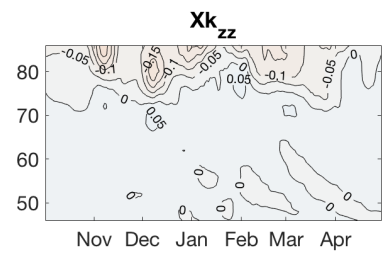

$80^{\circ} \mathrm{N}$
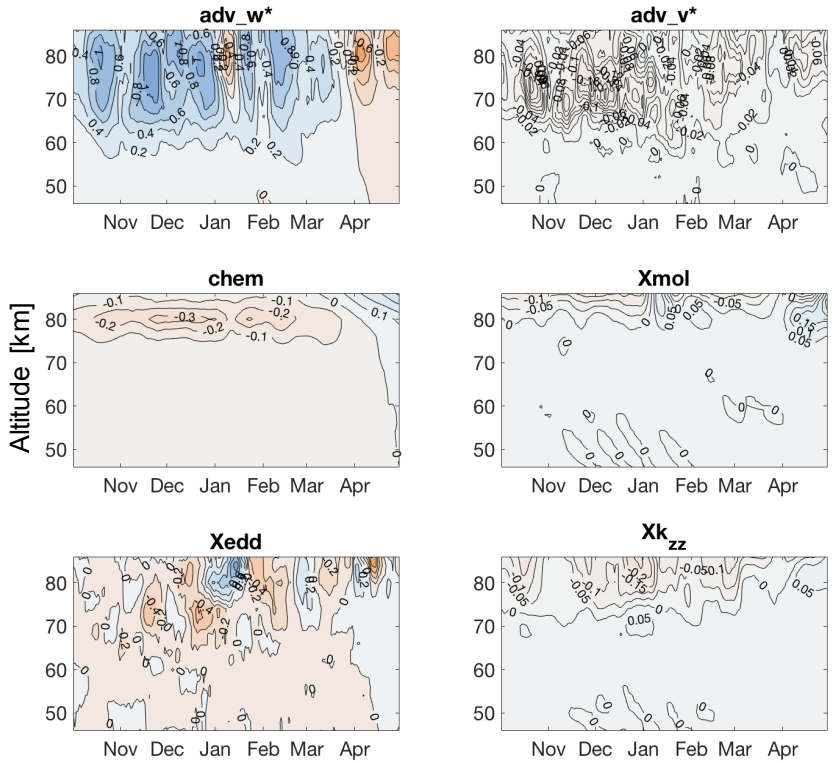

$\underline{2010 / 2011}$

Figure 4. The same as Fig. 3, but for $80^{\circ} \mathrm{N}$.
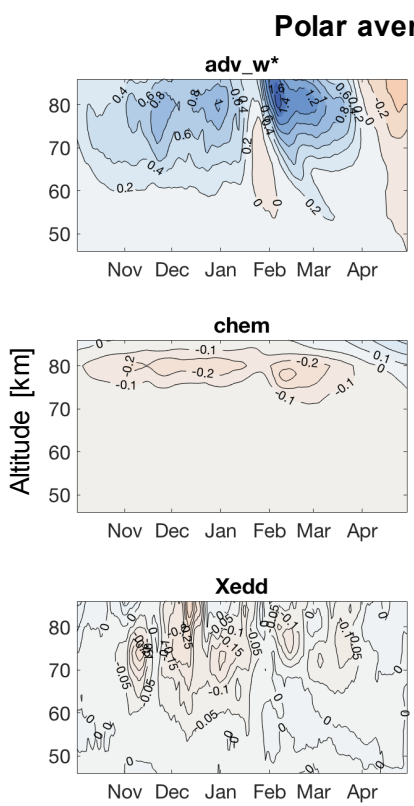

$\underline{2008 / 2009}$

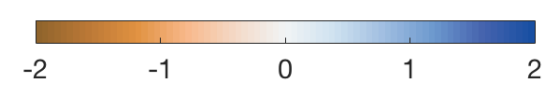

$\underline{2008 / 2009}$

$\left(60-90^{\circ} \mathrm{N}\right)$
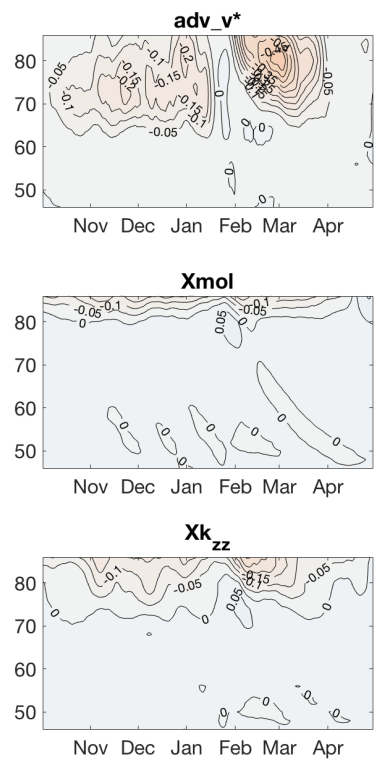
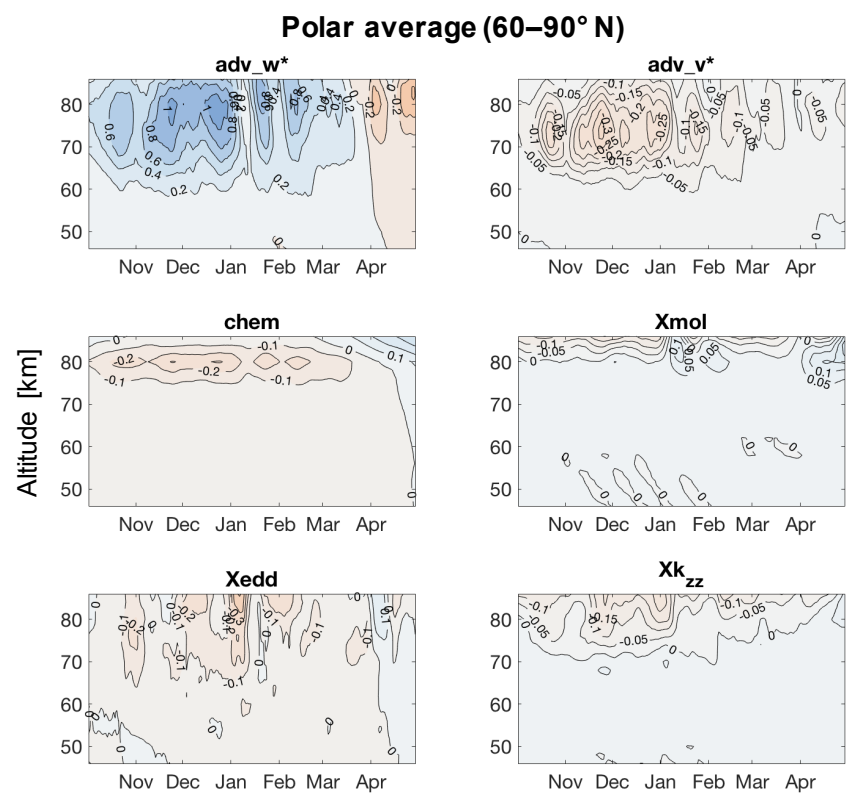

$\underline{2010 / 2011}$

Figure 5. The same as Fig. 3, but for the north polar average $\left(60-90^{\circ} \mathrm{N}\right)$.

$(z)$ vs. time $(t)$. The rate for a given date is calculated here by performing a regression on the $\mathrm{CO}$ data within \pm 5 days of the date. This gives an 11-day running mean of the rate of vertical motion. The calculation can be done for multiple
VMRs, to retrieve a vertical profile of the rates of vertical motion, as in Bailey et al. (2014). The term used here to denote the rate of vertical motion calculated using CO VMR is $w_{\text {CO }}$, following Hoffmann (2012). The second method used 


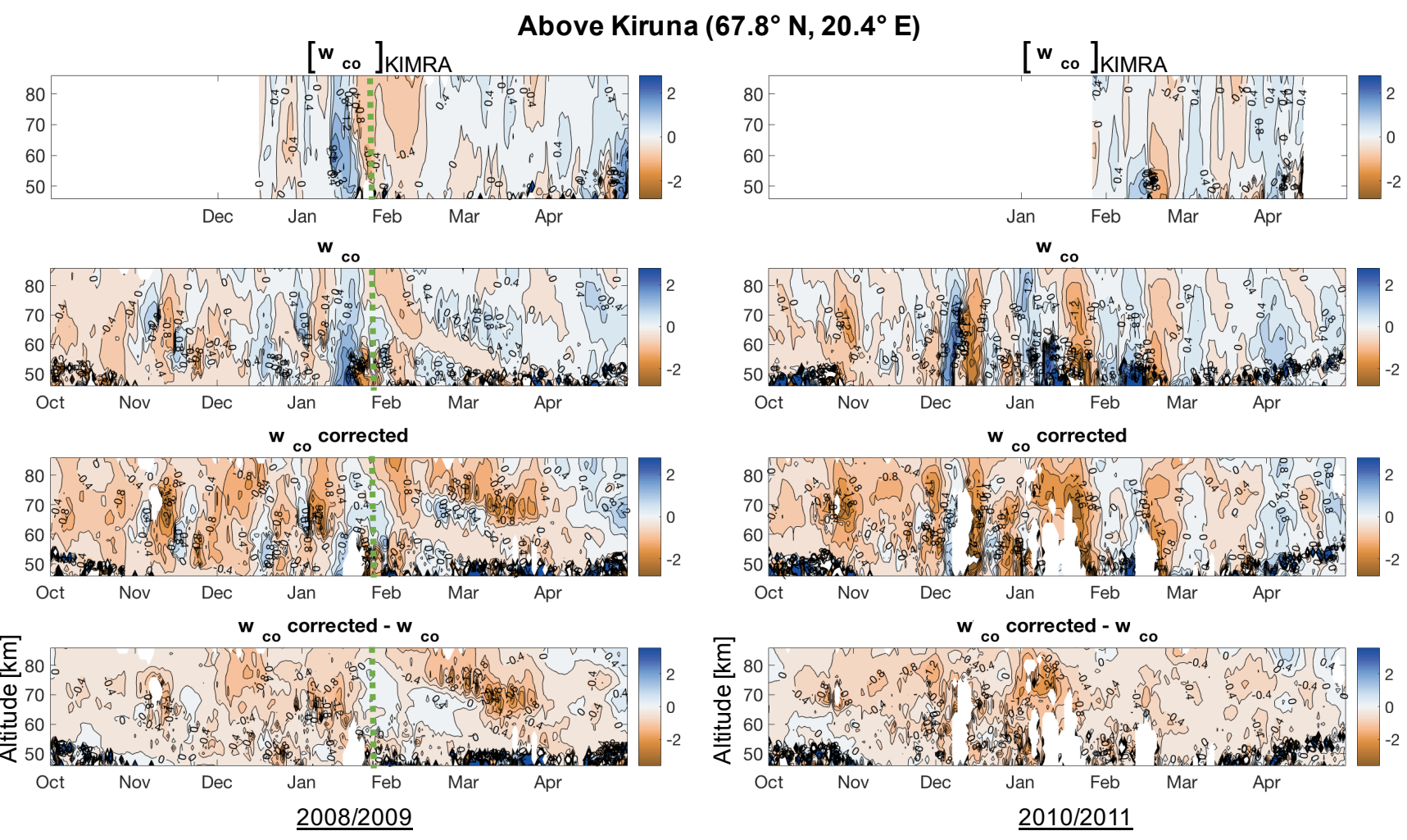

Figure 6. Rates of vertical motion, in $\mathrm{km} \mathrm{day}^{-1}$, calculated by tracking CO VMRs over time. $w_{\mathrm{CO}}$ is calculated using daily averaged SDWACCM CO profiles. $w_{\text {CO_corrected }}$ is calculated using a combination of SD-WACCM CO profiles and TEM tendencies (see Sect. 4 for details). The difference between the two rates of descent is also shown. The results plotted are for above Kiruna for the winters of 2008/2009 and 2010/2011. Contour lines are spaced by $0.2 \mathrm{~km}$ day $^{-1}$. Areas with tightly packed contours (black areas) occur when there are very low CO VMRs and the calculation method is unreliable. White areas are where a CO VMR could not be tracked within the shown altitude range. The start date of the SSW on 28 January 2009 is shown with a vertical green dashed line. Rates calculated using KIMRA CO data are also included in the upper two panels, titled $\left[w_{\mathrm{CO}}\right]_{\mathrm{KIMRA}}$.

here includes information on changes in CO VMRs due to all terms of the continuity equation in Sect. 2. Before tracking a CO VMR from one time step to the next, the VMR is adjusted using the tendencies of the continuity equation, except for $a d v \_w^{*}$, for the corresponding time frame. This accounts for changes in CO VMR from other processes as one tracks its movement due to vertical advection. The resulting rate is called $w_{\mathrm{CO} \_ \text {corrected }}$. This could be considered a crude approach, combining daily averaged $\mathrm{CO}$ output with $\mathrm{CO}$ tendencies calculated using the TEM formalism, but the aim here is to provide an estimate of the errors that may be incurred by neglecting influences on $\mathrm{CO}$ other than vertical advection. In any case, the results involving $w_{\mathrm{CO}}$ corrected are discussed in a qualitative manner, instead of for quantitative error analysis. To illustrate the difference between $w_{\mathrm{CO}}$ and $w_{\mathrm{CO} \_}$corrected, example algebraic expressions for the rates between a time step $n$ and $n+1$ are given: Eqs. (3), (4), and (5). In practice, $w_{\mathrm{CO}}$ and $w_{\mathrm{CO}}$ corrected were calculated by performing a linear regression on the 11-day altitude vs. time data, including errors in the estimated altitude of the measured CO VMRs. Equations (3), (4), and (5) refer to scalar (values at a given altitude/latitude/longitude) VMRs and tendencies, in contrast to Eqs. (1) and (2), which refer to threedimensional variables:

$$
\begin{aligned}
& w_{\mathrm{CO}}(z, t)=\left.\frac{z_{n+1}-z_{n}}{t_{n+1}-t_{n}}\right|_{\bar{\chi}}, \\
& w_{\mathrm{CO} \_ \text {corrected }}(z, t)=\frac{z\left(\bar{\chi}_{n+1}\right)-z\left(\bar{\chi}_{n}\right)}{t_{n+1}-t_{n}},
\end{aligned}
$$

where

$$
\begin{aligned}
\bar{\chi}_{n+1} & =\bar{\chi}_{n}+\left(\frac { 1 } { 2 } \sum _ { i = n } ^ { n + 1 } \left[\operatorname{adv}_{-} v^{*}+\text { chem }+\right.\right. \text { Xmol } \\
& \left.\left.+ \text { Xedd }+\mathrm{Xk}_{z z}\right]\right)\left(t_{n+1}-t_{n}\right) .
\end{aligned}
$$

The results for winters 2008/2009 and 2010/2011 are shown. For each winter, $w_{\mathrm{CO}}$ and $w_{\mathrm{CO} \_}$corrected are calculated as a local value above Kiruna, a zonal mean at $80^{\circ} \mathrm{N}$, and a polar mean $\left(60-90^{\circ} \mathrm{N}\right)$, and plotted in Figs. 6, 7, and 8, respectively. The methods above were found to be unreliable when there are very low CO VMRs, and gave unrealistic rates of motion. This was more likely to occur at lower altitudes 

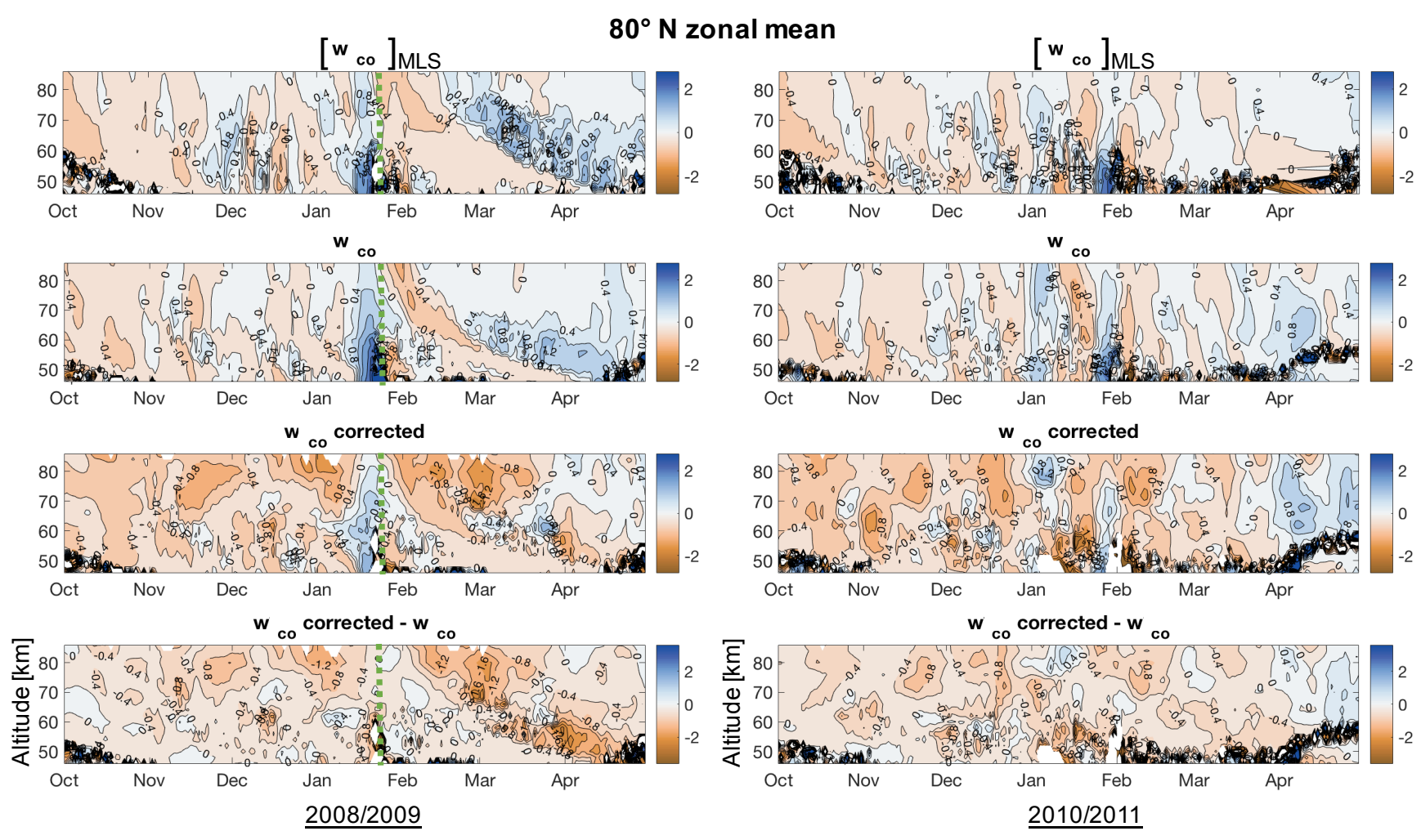

Figure 7. The same as Fig. 6, but for a zonal mean at $80^{\circ} \mathrm{N}$, and including rates calculated using MLS CO data in the upper two panels, titled $\left[w_{\mathrm{CO}}\right]_{\mathrm{MLS}}$.

where CO VMRs are relatively low. Sometimes a CO VMR could not be followed within the specified altitude range (no extrapolation was used) and so there are a few locations with no rate information. The differences between the two rates, $w_{\mathrm{CO} \_ \text {corrected }}-w_{\mathrm{CO}}$, are also shown in each panel. $w_{\mathrm{CO}}$ was also calculated using the data from KIMRA, for $67^{\circ} \mathrm{N}$, and from MLS, for the zonal mean at $80^{\circ} \mathrm{N}$ and the north polar mean. The results are included in Figs. 6-8 for comparison. The $w_{\mathrm{CO}}$ values from SD-WACCM and from the instruments show good agreement, with some differences that would be expected due to the levels of agreement of the $\mathrm{CO}$ VMRs (see Sect. 2). Considering the calculations using SDWACCM, there are three main qualitative points, common to each scenario and year, that are evident from the results. The same conclusions are reached when using KIMRA and MLS in place of SD-WACCM.

First, the values of $w_{\mathrm{CO}}$ are generally of a smaller magnitude than $w_{\mathrm{CO} \_}$corrected during winter, meaning the calculated rates of descent are stronger if one accounts for $\mathrm{CO}$ tendencies other than vertical advection. This makes sense because, as seen in Figs. 3-5, the other transport terms of the continuity equation (and the chemical loss term) tend to oppose the vertical advection term. In other words, the results indicate that the "true" rate of atmospheric descent is masked by sinks of $\mathrm{CO}$, and by transport processes that oppose the tendency due to vertical advection. Second, the differences between the two rates are often of the same order as $w_{\mathrm{CO}}$. Third, the signs of $w_{\mathrm{CO}}$ and $w_{\mathrm{CO}}$ corrected are often opposite, meaning the calculated direction of air motion is prone to change when accounting for $\mathrm{CO}$ tendencies other than vertical advection. In each example for 2008/2009, the magnitude of the positive (upward) motion around the time of SSW is decreased for $w_{\mathrm{CO}}$ corrected compared to $w_{\mathrm{CO}}$. After the SSW, and into March, the strongest descent values are seen around $70-80 \mathrm{~km}$ in $w_{\text {CO_corrected }}$, compared to values of ascent seen in $w_{\mathrm{CO}}$ at the same location.

\section{Relative strengths of $\mathrm{CO}$ tendencies, by month}

To give an idea of the relative influence each tendency has on middle-atmospheric CO VMRs each month, daily CO tendencies from 2008 to 2014 are used to provide relative values of their monthly mean. For a given tendency, the daily values are separated by calendar month and averaged, to give a monthly mean tendency. The daily sums of the absolute values of all tendencies are also separated by month and averaged, to give a monthly mean total absolute tendency. The monthly mean tendencies are then normalized by the monthly mean total absolute tendency, and will be referred to here as relative strengths. Using absolute values for normalization retains the sign of the individual tendencies and 


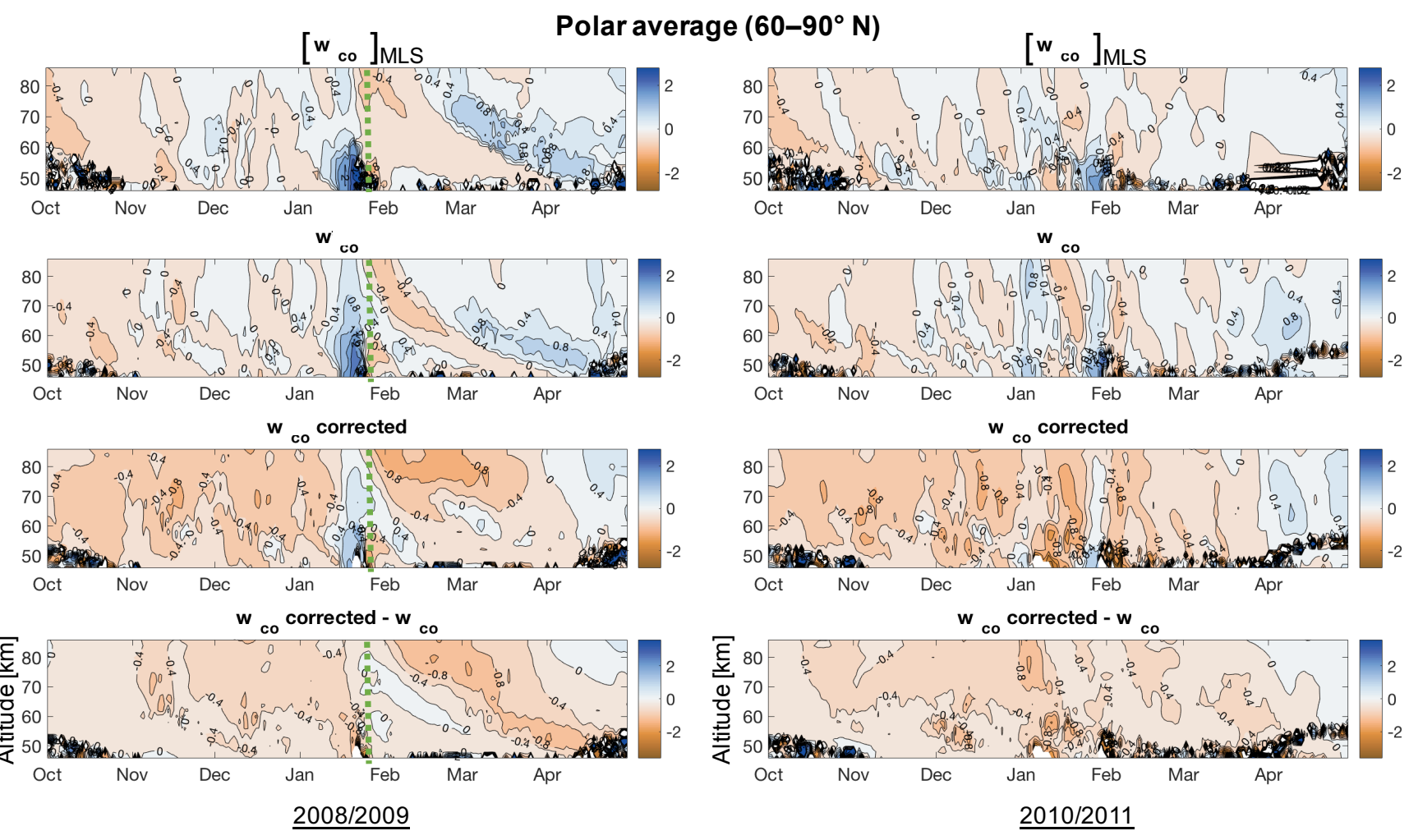

Figure 8. The same as Fig. 6, but for the north polar average $\left(60-90^{\circ} \mathrm{N}\right)$, and including rates calculated using MLS CO data in the upper panel, titled $\left[w_{\mathrm{CO}}\right]_{\mathrm{MLS}}$.

avoids a large spread in the results when there is a small denominator (i.e. when the tendencies cancel each other and their sum is near zero). The relative strength of the sum of all tendencies, excluding adv_ $w^{*}$, is also included as a variable. This variable will be referred to here as other processes and can be directly compared to the relative strength of adv_w*, to judge the influence of vertical advection compared to all other processes. The results are shown for the north polar average $\left(60-90^{\circ} \mathrm{N}\right)$ in Fig. 9, and the south polar average $\left(60-90^{\circ} \mathrm{S}\right)$ in Fig. 10. For the north, tendencies corresponding to the 10 days directly before and after a SSW (starting on 22, 24, and 26 January 2008, 2009, 2010, respectively, and 6 February 2013) are excluded from the calculation, as well as the SSW start date. A block of 10 days was chosen to remove effects directly before and after a SSW, but signatures of the events remain in the data. The information from before and after an SSW is used to separately calculate the relative strengths for these times and is shown in Fig. 11.

For the north polar average in Fig. 9, the relative strength of other processes is everywhere negative from October to March and the relative strength of adv_ $w^{*}$ is positive. Both adv_ $w^{*}$ and other processes show a change of sign in April. The relative strength of adv_ $w^{*}$ reaches a maximum value of 0.8 at lower altitudes in October and November, and decreases with altitude to approximately 0.5 at $86 \mathrm{~km}$ for these months. The relative strength of other processes shows an opposite trend: negative values strengthening with altitude to approximately -0.4 . At the lower limit of the altitude range in January, adv_ $w^{*}$ shows a lower relative strength than other processes due to a strong Xedd influence. This is likely the "left-over" influence of the SSWs in the data. By March, the relative strength of chem is prominent below $65 \mathrm{~km}$, and the magnitude of adv_w* is matched by other processes. By April, the residual mean circulation has reversed direction and adv_ $w^{*}$ has changed sign at most altitudes. The negative value of chem is then dominant at lower altitudes, and there is a stronger positive tendency above $\sim 80 \mathrm{~km}$ (from photolysis of carbon dioxide; $\mathrm{CO}_{2}$ ).

There are no months where the relative strength of other processes can be considered negligible compared to the relative strength of adv_w $w^{*}$. The closest approximations of this situation are at $50 \mathrm{~km}$ altitude in October and at $46 \mathrm{~km}$ altitude in November, when other processes contributes 13.7 and $9.6 \%$ of adv_ $w^{*}$, respectively. These percentages then vary significantly with altitude. For October, the value increases to $18.6 \%$ at $46 \mathrm{~km}, 22.5 \%$ at $60 \mathrm{~km}$, and is $61.13 \%$ at $80 \mathrm{~km}$. For November, the value increases to $34.4 \%$ at $54 \mathrm{~km}$, and is $70.8 \%$ at $80 \mathrm{~km}$.

The results for the south polar average, in Fig. 10, are qualitatively similar to those for the north. The relative strength of adv $\_w^{*}$ shows a maximum of $\sim 0.8$. Both hemispheres show a peak in chem at $80 \mathrm{~km}$ for most of winter (see Sect. 3.3). 


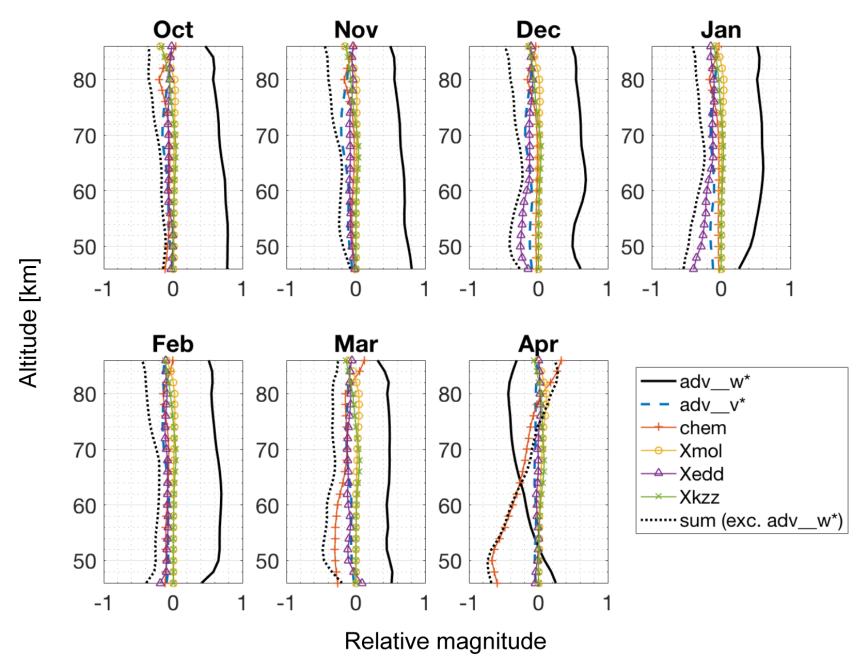

Figure 9. North polar average $\left(60-90^{\circ} \mathrm{N}\right)$ monthly mean $\mathrm{CO}$ tendencies (see Eq. 2) around winter time, calculated using SDWACCM output from January 2008 to April 2014. Model output corresponding to 10 days directly before and after a SSW, as well as the start date, is excluded. The values are expressed relative to the monthly means of the sum of the absolute values of all tendencies at a given altitude, and are referred to as relative strengths (see Sect. 5). A relative strength of the sum of the tendencies, excluding adv_ $w^{*}$, is also plotted.

The relative strength of Xedd is not as prominent at the south as the north, likely due to the higher stability of the southern polar vortex. The points at which the relative strength of other processes is smallest compared to adv_w* are at $56 \mathrm{~km}$ in April $(8.3 \%)$ and at $46 \mathrm{~km}$ in May $(6.8 \%)$. For April, the value increases to $22.5 \%$ at $46 \mathrm{~km}$ and $21.5 \%$ at $66 \mathrm{~km}$, and is $56.9 \%$ at $80 \mathrm{~km}$. In May, the value increases to $16 \%$ at $54 \mathrm{~km}$, and is $69.1 \%$ at $80 \mathrm{~km}$.

For the 10 days directly before and after SSWs, in Fig. 11, the relative strength of adv_w* is less than 0.5 at all altitudes. Xedd is strong below $60 \mathrm{~km}$, such that the relative strength of other processes has a larger magnitude than that of adv_w* at many altitudes. The relative strength of adv_w* shows a more oscillatory structure with altitude, and there is a local minimum at about $70 \mathrm{~km}$ in the data for 10 days after SSWs. There is also a positive peak in the relative strength of $\mathrm{Xk}_{z z}$ after SSWs at this altitude.

Aside from considering what value would classify as negligible, the significant variation in strength of other processes compared to adv_ $w^{*}$, over altitude, adds complexity to the method of following a tracer over an altitude range to determine the descent rate. One must also consider that while this section discusses monthly averaged data, tracers are often followed for several days to determine the changes in altitude over that time, and that the magnitudes of each tendency can vary significantly over this timescale (see Figs. 3, 4, and 5).

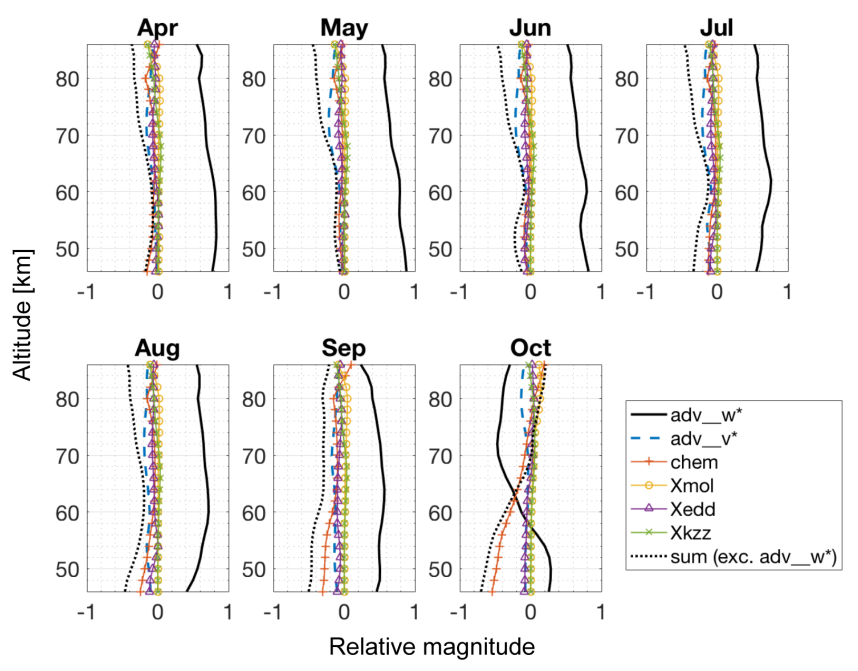

Figure 10. Same plots as for Fig. 9, but for the south polar average $\left(60-90^{\circ} \mathrm{S}\right)$, around the time of southern hemisphere winter, and with no exclusion of model output for SSWs.
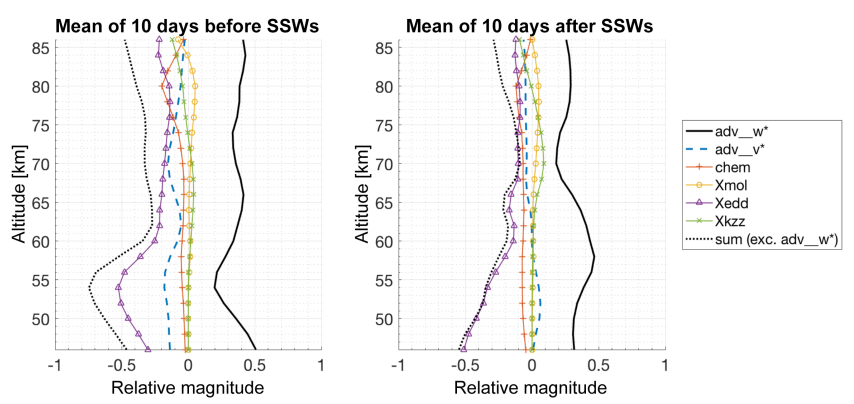

Figure 11. Same as Fig. $9\left(60-90^{\circ} \mathrm{N}\right)$, but for the 10 days directly before and after SSWs within Jan 2008 to April 2014. See Sect. 5 for details.

\section{Discussion}

The results of the previous sections, using SD-WACCM, are clear on one indication - that the assumption of observed changes in CO VMRs being solely due to vertical advection is not a valid one. What is not obvious, is what the rates inferred from the behaviour of tracer isolines $\left(w_{\chi}\right.$, under the nomenclature used here) represent. When making observations on timescales of weeks, the TEM offers a suitable representation of the governing dynamics. The vertical velocities calculated by observing $\mathrm{CO}$, however, are smaller than the magnitudes of the TEM vertical wind, $\overline{w^{*}}$, found with SD-WACCM. Figure 12 shows the polar average (60$\left.90^{\circ} \mathrm{N}\right) \overline{w^{*}}$ for the winters of 2008/2009 and 2010/2011, calculated using daily averaged SD-WACCM output. Compar-

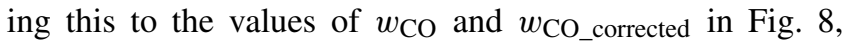
it is clear that the rates derived from $\mathrm{CO}$ values are generally of lower magnitude than $\overline{w^{*}}$. This agrees with the results of Hoffmann (2012). $w_{\text {CO_corrected }}$ more closely matches the 

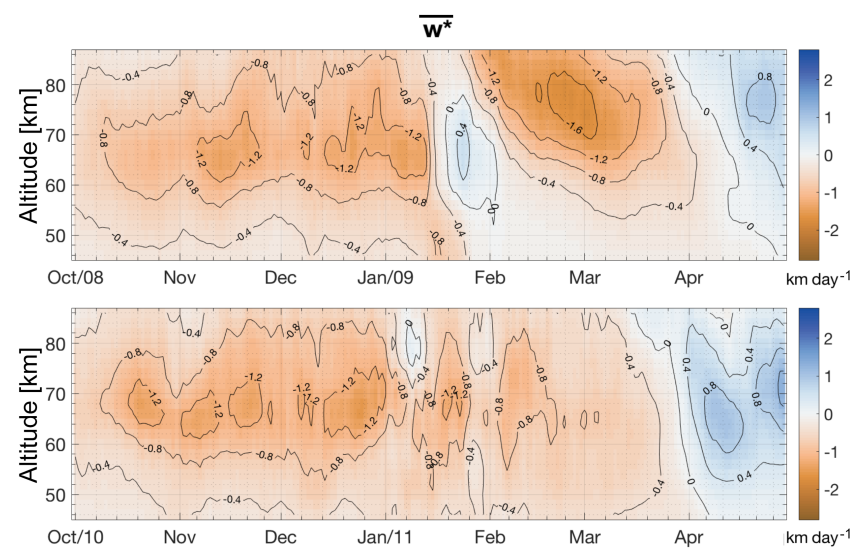

Figure 12. The north polar average $\left(60-90^{\circ} \mathrm{N}\right)$ TEM vertical wind, $\overline{w^{*}}$, for the winters of 2008/2009, and 2010/2011. The values are calculated using daily averaged output from SD-WACCM.

sign and general pattern of $\overline{w^{*}}$, but does not reach the semipersistent descent rates of $-1.2 \mathrm{~km} \mathrm{day}^{-1}$ between 60 and $70 \mathrm{~km}$, or the magnitude of the enhanced rate of descent $\left(<-1.6 \mathrm{~km} \mathrm{day}^{-1}\right)$ after the SSW in 2009. Similar results are observed when using KIMRA and MLS CO profiles to derive vertical velocity, instead of SD-WACCM output (not shown here).

Some of the difference may be attributed to the time resolution, or assumed parameters, of the SD-WACCM output used in this work. Meraner and Schmidt (2016) showed that the tendency of NO due to $\overline{w^{*}}$ can be quite different (by $>1 \mathrm{ppm} \mathrm{day}^{-1}$ at $90 \mathrm{~km}$ ) when calculated using $6 \mathrm{~h}$ averaged output or daily averaged output from HAMMONIA (Hamburg Model of the Neutral and Ionized Atmosphere). Meraner et al. (2016) showed that $\mathrm{NO}_{x}$ transport in the mesosphere is highly sensitive to the strength of the gravity wave source. The amplitudes of gravity waves influence the altitude at which the waves break and deposit their momen-

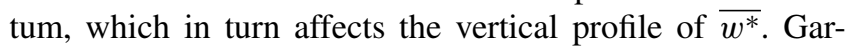
cia et al. (2014) found that using a Prandtl number of 4 for WACCM (see Sect. 3.1), instead of 2 (as used here), gave better agreement with polar $\mathrm{CO}$ profiles from satellite instruments (the Atmospheric Chemistry Experiment Fourier Transform Spectrometer (ACE-FTS) on SCISAT-1, and the Michelson Interferometer for Passive Atmospheric Sounding (MIPAS) on Envisat). The opposite was found for tropical and mid-latitude CO profiles, and Garcia et al. (2014) consider that deficiencies in the modelling of diffusive eddy transport may be due to problems in producing the correct latitudinal profile of $K_{z z}$, which cannot be addressed by simply adjusting the Prandtl number.

As the results here using SD-WACCM indicate that the commonly used approximation of $\overline{w^{*}}$ with $w_{\chi}$ (using tracer observations) is not valid, we suggest an alternative interpretation of $w_{\chi}$ : as an effective rate of vertical transport for the trace gas $\chi$. The interpretation still concerns the descent of a tracer through the middle atmosphere, but allows for a chemical sink, or for processes other than vertical advection to influence the descent rate, e.g. horizontal advection or an increase in unresolved eddy transport after a SSW. Hoffmann (2012) put forward a similar interpretation for $w_{\mathrm{CO}}$, but with an assumption that the overall dynamic effects on $\mathrm{CO}$ are representative for mesospheric air, and so $w_{\mathrm{CO}}$ is representative of $w_{\chi}$ for all tracers. The results here do not confirm that assumption, as it would require tracers to have the same horizontal and vertical VMR gradients (see Sect. 2.5 and references therein). The consistent negative chemical tendency of $\mathrm{CO}$, seen here in a layer around approximately $80 \mathrm{~km}$, also indicates the need to account for the behaviour of chemical sinks, even during polar night.

\section{Conclusions}

The aim of this work was to assess how well polar atmospheric descent rates can be derived from remote sensing measurements of atmospheric trace gases. Tendencies of middle atmospheric $\mathrm{CO}$ were calculated using output from SD-WACCM for the years 2008 to 2014, within $46-86 \mathrm{~km}$ altitude, and used to evaluate the relative influence of processes involved in the TEM CO continuity equation. The results show that dynamical processes other than vertical advection cause non-negligible changes in CO VMRs during winter, and particularly directly before and after sudden stratospheric warmings when eddy transport can become dominant. Significant changes in $\mathrm{CO}$ tendencies from SDWACCM occur over timescales of the order of days. The results also show a chemical sink for $\mathrm{CO}$, present throughout polar night, due to the layer of night-time $\mathrm{OH}$ at approximately $80 \mathrm{~km}$. Modelled CO profiles were used in combination with the tendency data to provide a qualitative estimate of the errors that can be incurred when assuming pure vertical advection of CO. Rates of atmospheric motion were calculated when assuming only vertical advection, and corrected rates were calculated by including tendency information for all processes. The differences between the two results are of the same order as the calculated rates, and the rates are prone to showing opposite directions for the mean vertical wind. The corrected rates more closely match the TEM vertical wind velocity from SD-WACCM, but both results using CO show smaller magnitudes relative to the TEM vertical wind, in agreement with the work of Hofmann (2012). The "true" rate of atmospheric descent appears to be masked by sinks of $\mathrm{CO}$, and by transport processes that oppose the tendency due to vertical advection. Monthly mean relative tendencies for $\mathrm{CO}$ show that the summed magnitude of processes other than vertical advection can constitute a large fraction of the changes in CO VMR. For a given month, the summed magnitude of the other processes, relative to vertical advection, changes by several tens of percent over the altitude range under investigation. The results here suggest that there are 
no months during polar winter when vertical mean advection dominates the budget of $\mathrm{CO}$ to such an extent that vertical mean velocity can be accurately derived within the altitude range.

An assessment using SD-WACCM indicates that a commonly used approximation of the vertical mean velocity of the atmosphere, $\overline{w^{*}}$, using tracer (CO in this case) isolines is not valid, and an alternative interpretation of the rates derived from trace gas measurements is suggested: an effective rate of vertical transport for the given trace gas. Such an interpretation still concerns the descent of trace gases from the mesosphere and thermosphere, but allows for chemical sinks, and changes in VMR from dynamical processes other than vertical advection. Due to possible differences in the behaviour of chemical sinks and VMR gradients, it is not clear whether the rate of vertical transport for one tracer is representative of the rate for another. Continuous ground-based and satellite measurements of trace gases remain an essential tool in understanding the short- and long-term evolution of the middle atmosphere, as well as for the validation and parameterization of atmospheric models.

Data availability. The KIMRA CO data set (between December 2008 and May 2015) can be accessed publicly through PANGAEA Data Publisher for Earth and Environmental Science at https://doi.org/10.1594/PANGAEA.861730 (Ryan et al., 2017b). Model results shown in this paper are available on request via Doug Kinnison (dkin@ucar.edu). The Aura MLS v4.2 data are available from the Goddard Earth Sciences Data and Information Center at https://disc.gsfc.nasa.gov.

Author contributions. MP and CGH outlined the project. NJR designed the method. DEK performed the SD-WACCM runs and provided the output. RRG provided scripts to calculate TEM variables from WACCM output. UR maintains and operates KIMRA, and provided the instrument spectra. NJR performed the study with valuable insight and interpretation of results provided by DEK and RRG. JN oversaw project development. NJR prepared the paper with contributions from co-authors.

Competing interests. The authors declare that they have no conflict of interest.

Acknowledgements. A 3-month research stay by Niall J. Ryan at the National Centre for Atmospheric Research, Boulder, Colorado, was funded by the University of Bremen, under the German Excellence Initiative (ABPZuK-03/2014). Instrument data used in the project were developed and acquired through funding from the German Federal Ministry of Education and Research (BMBF) through the research project "Role Of the Middle atmosphere in Climate" (ROMIC), sub-project ROMICCO, project number 01LG1213A. The paper creation and editing was supported through ROMICCO. We would like to thank the National Center for Atmospheric Research (NCAR) for being so accommodating. The National Center for Atmospheric Research is sponsored by the US National Science Foundation. We express our gratitude to the MLS team for making their data available. A special thank you to Sophia McCue, for all the smiles.

The article processing charges for this open-access publication were covered by the University of Bremen.

Edited by: William Ward

Reviewed by: four anonymous referees

\section{References}

Allen, D. R., Stanford, J. L., López-Valverde, M. A., Nakamura, N., Lary, D. J., Douglass, A. R., Cerniglia, M. C., Remedios, J. J., and Taylor, F. W.: Observations of Middle Atmosphere CO from the UARS ISAMS during the Early Northern Winter 1991/92, J. Atmos. Sci., 56, 563-583, 1999.

Allen, D. R., Stanford, J. L., Nakamura, N., López-Valverde, M. A., López-Puertas, M., Taylor, F. W., and Remedios, J. J.: Antarctic polar descent and planetary wave activity observed in ISAMS CO from April to July 1992, Geophys. Res. Lett., 27, 665-668, 2000.

Andrews, D., Holton, J., and Leovy, C.: Middle Atmosphere Dynamics, Academic Press, 489 pp., 1987.

Andrews, D. G. and McIntyre, M. E.: Planetary waves in horizontal and vertical shear: The generalized Eliassen-Palm relation and mean zonal acceleration, J. Atmos. Sci., 33, 2031-2048, 1976.

Bailey, S. M., Thurairajah, B., Randall, C. E., Holt, L., Siskind, D. E., Harvey, V. L., Venkataramani, K., Hervig, M. E., Rong, P., and Russell III, J. M.: A multi tracer analysis of thermosphere to stratosphere descent triggered by the 2013 Stratospheric Sudden Warming, Geophys. Res. Lett., 41, 5216-5222, https://doi.org/10.1002/2014GL059860, 2014.

Barth, C. A. and Bailey S. M.: Comparison of a thermospheric photochemicalmodel with SNOE observations of nitric oxide, J. Geophys. Res., 109, A03304, https://doi.org/10.1029/2003JA010227, 2004.

Brasseur, G. and Solomon, S.: Aeronomy of the Middle Atmosphere: Chemistry and Physics of the Stratosphere and Mesosphere, Springer, 644 pp., 2005.

Brewer, A. W.: Evidence for a world circulation provided by the measurements of helium and water vapour distribution in the stratosphere, Q. J. Roy. Meteor. Soc., 75, 351-363, https://doi.org/10.1002/qj.49707532603, 1949.

Brinksma, E. J., Meijer, Y. J., McDermid, I. S., Cageao, R. P., Bergwerff, J. B., Swart, D. P. J., Ubachs, W., Matthews, W. A., Hogervorst, W., and Hovenier, J. W.: First lidar observations of mesospheric hydroxyl, Geophys. Res. Lett., 25, 51-54, 1998.

Damiani, A., Storini, M., Santee, M. L., and Wang, S.: Variability of the nighttime $\mathrm{OH}$ layer and mesospheric ozone at high latitudes during northern winter: influence of meteorology, Atmos. Chem. Phys., 10, 10291-10303, https://doi.org/10.5194/acp-10-102912010, 2010.

Di Biagio, C. D., Muscari, G., di Sarra, A., de Zafra, R. L., Eriksen, P., Fiocco, G., Fiorucci, I., and Fuà, D.: Evolution of temperature, $\mathrm{O}_{3}, \mathrm{CO}$, and $\mathrm{N}_{2} \mathrm{O}$ profiles dur- 
ing the exceptional 2009 Arctic major stratospheric warming observed by lidar and mm-wave spectroscopy at Thule $\left(76.5^{\circ} \mathrm{N}, 68.8^{\circ} \mathrm{W}\right)$, Greenland, J. Geophys. Res., 115, D24315, https://doi.org/10.1029/2010JD014070, 2010.

Dunkerton, T.: On the mean meridional mass motions of the stratosphere and mesosphere, J. Atmos. Sci., 25, 2325-2333, 1978.

Engel, A., Möbius, T., Haase, H.-P., Bönisch, H., Wetter, T., Schmidt, U., Levin, I., Reddmann, T., Oelhaf, H., Wetzel, G., Grunow, K., Huret, N., and Pirre, M.: Observation of mesospheric air inside the arctic stratospheric polar vortex in early 2003, Atmos. Chem. Phys., 6, 267-282, https://doi.org/10.5194/acp-6-267-2006, 2006.

Forkman, P., Eriksson, P., and Murtagh, D.: Observing the vertical branch of the mesospheric circulation at lat $\mathrm{N} 60^{\circ}$ using ground based measurements of $\mathrm{CO}$ and $\mathrm{H}_{2} \mathrm{O}$, J. Geophys. Res., 110, D05107, https://doi.org/10.1029/2004JD004916, 2005.

Fritts, C. D. and Dunkerton, T. J.: Fluxes of Heat and Constituents Due to Convectively Unstable Gravity Waves, J. Atmos. Sci., 42, 549-556, 1985.

Funke, B., López-Puertas, M., García-Comas, M., Stiller, G. P., von Clarmann, T., Höpfner, M., Glatthor, N., Grabowski, U., Kellmann, S., and Linden, A.: Carbon monoxide distributions from the upper troposphere to the mesosphere inferred from $4.7 \mu \mathrm{m}$ non-local thermal equilibrium emissions measured by MIPAS on Envisat, Atmos. Chem. Phys., 9, 2387-2411, https://doi.org/10.5194/acp-9-2387-2009, 2009.

Funke, B., López-Puertas, M., Stiller, G. P., and von Clarmann, T.: Mesospheric and stratospheric NOy produced by energetic particle precipitation during 2002-2012, J. Geophys. Res., 119, 4429-4446, https://doi.org/10.1002/2013JD021404, 2014a.

Funke, B., Puertas, M. L., Holt, L., Randall, C. E., Stiller, G. P., and von Clarmann, T.: Hemispheric distributions and interannual variability of NOy produced by energetic particle precipitation in 2002-2012, J. Geophys. Res., 119, 13565-13582, https://doi.org/10.1002/2014JD022423, 2014b.

Funke, B., Ball, W., Bender, S., Gardini, A., Harvey, V. L., Lambert, A., López-Puertas, M., Marsh, D. R., Meraner, K., Nieder, H., Päivärinta, S.-M., Péot, K., Randall, C. E., Reddmann, T., Rozanov, E., Schmidt, H., Seppälä, A., Sinnhuber, M., Sukhodolov, T., Stiller, G. P., Tsvetkova, N. D., Verronen, P. T., Versick, S., von Clarmann, T., Walker, K. A., and Yushkov, V.: HEPPA-II model-measurement intercomparison project: EPP indirect effects during the dynamically perturbed NH winter 2008-2009, Atmos. Chem. Phys., 17, 35733604, https://doi.org/10.5194/acp-17-3573-2017, 2017.

Garcia, R., Marsh, D., Kinnison, D., Boville, B., and Sassi, F.: Simulation of secular trends in the middle atmosphere, 1950-2003, J. Geophys. Res., 112, D09301, https://doi.org/10.1029/2006JD007485, 2007.

Garcia, R. R. and Solomon, S.: A Numerical Model of the Zonally Averaged Dynamical and Chemical Structure of the Middle Atmosphere, J. Geophys. Res., 88, 1379-1400, https://doi.org/10.1029/JC088iC02p01379, 1983.

Garcia, R. R., López-Puertas, M., Funke, D., Marsh, D. R., Kinnison, D. E., Smith, A. K., and González-Galindo, F.: On the distribution of $\mathrm{CO}_{2}$ and $\mathrm{CO}$ in the mesosphere and lower thermosphere, J. Geophys. Res., 119, 5700-5718, https://doi.org/10.1002/2013JD021208, 2014.
Harvey, V. L., Randall, C. E., and Hitchman, M. H.: Breakdown of potential vorticity-based equivalent latitude as a vortex-centered coordinate in the polar winter mesosphere, J. Geophys. Res., 114, D22105, https://doi.org/10.1029/2009JD012681, 2009.

Harvey, V. L., Randall, C. E., and Collins, R. L.: Chemical definition of the mesospheric polar vortex, J. Geophys. Res.-Atmos., 120, 10166-10179, https://doi.org/10.1002/2015JD023488, 2015.

Hauchecorne, A., Bertaux, J.-L., Dalaudier, F., Russell III, J. M., Mlynczak, M. G., Kyrölä, E., and Fussen, D.: Large increase of $\mathrm{NO}_{2}$ in the north polar mesosphere in January-February 2004: Evidence of a dynamical origin from GOMOS/ENVISAT and SABER/TIMED data, Geophys. Res. Lett., 34, L03810, https://doi.org/10.1029/2006GL027628, 2007.

Hoffmann, C. G.: Application of $\mathrm{CO}$ as a tracer for dynamics in the polar winter middle atmosphere, $\mathrm{PhD}$ thesis, Institut für Umweltphysik, Universität Bremen, Germany, 142 pp., 2012.

Hoffmann, C. G., Raffalski, U., Palm, M., Funke, B., Golchert, S. H. W., Hochschild, G., and Notholt, J.: Observation of stratomesospheric $\mathrm{CO}$ above Kiruna with ground-based microwave radiometry - retrieval and satellite comparison, Atmos. Meas. Tech., 4, 2389-2408, https://doi.org/10.5194/amt-4-2389-2011, 2011.

Hoffmann, C. G., Kinnison, D. E., Garcia, R. R., Palm, M., Notholt, J., Raffalski, U., and Hochschild, G.: CO at 40-80 km above Kiruna observed by the ground-based microwave radiometer KIMRA and simulated by the Whole Atmosphere Community Climate Model, Atmos. Chem. Phys., 12, 3261-3271, https://doi.org/10.5194/acp-12-3261-2012, 2012.

Holt, L. A., Randall, C. E., Peck, E. D., Marsh, D. R., Smith, A. K., and Harvey, V. L.: The influence of major sudden stratospheric warming and elevated stratopause events on the effects of energetic particle precipitation in WACCM, J. Geophys. Res., 118, 636-646, 2013.

Jackman, C. H., Marsh, D. R., Vitt, F. M., Garcia, R. R., Randall, C. E., Fleming, E. L., and Frith, S. M.: Long-term middle atmospheric influence of very large solar proton events, J. Geophys. Res., 114, D11304, https://doi.org/10.1029/2008JD011415, 2009.

Jin, J. J., Semeniuk, K., Manney, G. L., Jonsson, A. I., Beagley, S. R., McConnell, J. C., Dufour, G., Nassar, R., Boone, C. D., Walker, K. A., Bernath, P. F., and Rinsland, C. P.: Severe Arctic ozone loss in the winter 2004/2005: observations from ACE-FTS, Geophys. Res. Lett., 33, L15801, https://doi.org/10.1029/2006GL026752, 2006.

Kinnison, D. E., Brasseur, G. P., Walters, S., Garcia, R. R., Marsh, D. R., Sassi, F., Harvey, V. L., Randall, C. E., Emmons, L., Lamarque, J. F., Hess, P., Orlando, J. J., Tie, X. X., Randel, W., Pan, L. L., Gettelman, A., Granier, C., Diehl, T., Niemeier, U., and Simmons, A. J.: Sensitivity of chemical tracers to meteorological parameters in the MOZART3 chemical transport model, J. Geophys. Res., 112, D20302, https://doi.org/10.1029/2006JD007879, 2007.

Lamarque, J.-F., Emmons, L. K., Hess, P. G., Kinnison, D. E., Tilmes, S., Vitt, F., Heald, C. L., Holland, E. A., Lauritzen, P. H., Neu, J., Orlando, J. J., Rasch, P. J., and Tyndall, G. K.: CAM-chem: description and evaluation of interactive atmospheric chemistry in the Community Earth System Model, Geosci. Model Dev., 5, 369-411, https://doi.org/10.5194/gmd-5369-2012, 2012. 
Lee, J. N., Wu, D. L., Manney, G. L., Schwartz, M. J., Lambert, A., Livesey, N. J., Minschwaner, K. R., Pumphrey, H. C., and Read, W. G.: Aura Microwave Limb Sounder observations of the polar middle atmosphere: Dynamics and transport of $\mathrm{CO}$ and $\mathrm{H}_{2} \mathrm{O}$, J. Geophys. Res., 116, D05110, https://doi.org/10.1029/2010JD014608, 2011.

Lieberman, R. S., Smith, A. K., Franke, S. J., Vincent, R. A., Isler, J. R., Manson, A. H., Meek, C. E., Fraser, G. J., Fahrutdinova, A., Thayaparan, T., Hocking, W., MacDougall, J., Nakamura, T., and Tsuda, T.: Comparison of mesospheric and lower thermospheric residual wind with High Resolution Doppler Imager, medium frequency, and meteor radar winds, J. Geophys. Res., 105, 27023-27035, 2000.

Lin, S.-J.: A “vertically-Lagrangian” finite-volume dynamical core for global atmospheric models, Mon. Weather Rev., 132, 22932307, 2004.

Livesey, N. J., Livesey, Filipiak, M. J., Froidevaux, L., Read, W. G., Lambert, A., Santee, M. L., Jiang, J. H., Waters, J. W., Cofield, R. E., Cuddy, D. T., Daffer, W. H., Drouin, B. J., Fuller, R. A., Jarnot, R. F., Jiang, Y. B., Knosp, B. W., Li, Q. B., Perun, V. S., Schwartz, M. J., Snyder, W. V., Stek, P. C., Thurstans, R. P., Wagner, P. A., Pumphrey, H. C., Avery, M., Browell, E. V., Cammas, J.-P., Christensen, L. E., Edwards, D. P., Emmons, L. K., Gao, R.-S., Jost, H.-J., Loewenstein, M., Lopez, J. D., Nedelec, P., Osterman, G. B., Sachse, G. W., and Webster, C. R: Validation of Aura Microwave Limb Sounder $\mathrm{O}_{3}$ and $\mathrm{CO}$ observations in the upper troposphere and lower stratosphere, J. Geophys. Res., 113, D15S02, https://doi.org/10.1029/2007JD008805, 2008.

Livesey, N. J., Read, W. G., Wagner, P. A., Froidevaux, L., Lambert, A., Manney, G. L., Millán Valle, L. F., Pumphrey, H. C., Santee, M. L., Schwartz, M. J., Wang, S., Fuller, R. A., Jarnot, R. F., Knosp, B. W., and Martinez, E.: Version 4.2x Level 2 data quality and description document, Tech. rep., Jet Propulsion Laboratory, 2015.

Liu, H., Foster, B. T., Hagan, M. E., McInerney, J. M., Maute, A., Qian, L., Richmond, A. D., Roble, R. G., Solomon, S. C., Garcia, R. R., Kinnison, D., Marsh, D. R., Smith, A. K., Richter, J., Sassi, F., and Oberheide, J.: Thermosphere extension of the Whole Atmosphere Community Climate Model, J. Geophys. Res., 115, A12302, https://doi.org/10.1029/2010JA015586, 2010.

Manney, G. L., Zurek, R. W., O’Neill, A., Swinbank, R., Kumer, J. B., Mergenthaer, J. L., and Roche A. E.: Stratospheric warmings during February and March 1993, Geophys. Res. Lett., 21, 813816, 1994.

Manney, G. L., Froidevaux, L., Santee, M. L., Zurek, R. W., and Waters, J. W.: MLS Observations of Arctic Ozone Loss in 1996-97, Geophys. Res. Lett., 24, 2697-2700, https://doi.org/10.1029/97GL52827, 1997.

Manney, G. L., Froidevaux, L., Santee, M. L., Livesey, N. J., Sabutis, J. L., and Waters J. W.: Variability of ozone loss during Arctic winter (1991-2000) estimated from UARS Microwave Limb Sounder measurements, J. Geophys. Res., 108, 4149, https://doi.org/10.1029/2002JD002634, 2003.

Manney, G. L., Daffer, W. H., Zawodny, J. M., Bernath, P. F., Hoppel, K. W., Walker, K. A., Knosp, B. W., Boone, C., Remsberg, E. E., Santee, M. L., Harvey, V. L., Pawson, S., Jackson, D. R., Deaver, L., McElroy, C. T., McLinden, C. A., Drummond, J. R., Pumphrey, H. C., Lambert, A., Schwartz, M. J., Froidevaux, L., McLeod, S., Takacs, L. L., Suarez, M. J., Trepte,
C. R., Cuddy, D. C., Livesey, N. J., Harwood, R. S., and Waters, J. W.: Solar occultation satellite data and derived meteorological products: sampling issues and comparisons with Aura Microwave Limb Sounder, J. Geophys. Res., 112, D24S50, https://doi.org/10.1029/2007JD008709, 2007.

Manney, G. L., Daffer, W. H., Strawbridge, K. B., Walker, K. A., Boone, C. D., Bernath, P. F., Kerzenmacher, T., Schwartz, M. J., Strong, K., Sica, R. J., Krüger, K., Pumphrey, H. C., Lambert, A., Santee, M. L., Livesey, N. J., Remsberg, E. E., Mlynczak, M. G., and Russell III, J. R.: The high Arctic in extreme winters: vortex, temperature, and MLS and ACE-FTS trace gas evolution, Atmos. Chem. Phys., 8, 505-522, https://doi.org/10.5194/acp-8505-2008, 2008a.

Manney, G. L., Krüger, K., Pawson, S., Minschwaner, K., Schwartz, M. J., Daffer, W. H., Livesey, N. J., Mlynczak, M. G., Remsberg, E. E., Russell, J. M., and Waters, J. W.: The evolution of the stratopause during the 2006 major warming: Satellite data and assimilated meteorological analyses, J. Geophys. Res., 113, D11115, https://doi.org/10.1029/2007JD009097, 2008b.

Manney, G. L., Schwartz, M. J., Krüger, K., Santee, M. L., Pawson, S., Lee, J. N., Daffer, W. H., Fuller, R. A., and Livesey, N. J.: Aura Microwave Limb Sounder observations of dynamics and transport during the record-breaking 2009 Arctic stratospheric major warming, Geophys. Res. Lett., 36, L12815, https://doi.org/10.1029/2009GL038586, 2009.

Manney, G. L., Lawrence, Z. D., Santee, M. L., Read, W. G., Livesey, N. J., Lambert, A., Froidevaux, L., Pumphrey, H. C., and Schwartz, M. J.: A minor sudden stratospheric warming with a major impact: Transport and polar processing in the 2014/2015 Arctic winter, Geophys. Res. Lett., 42, 7808-7816, https://doi.org/10.1002/2015GL065864, 2015.

Marsh, D. R., Mills, M. J., Kinnison, D. E., Lamarque, J.-F., Calvo, N., and Polvani, L. M.: Climate change from 1850 to 2005 simulated in CESM1 (WACCM), J. Climate, 26, 7372-7391, https://doi.org/10.1175/JCLI-D-12-00558.1, 2013.

McLandress, C., Scinocca, J. F., Shepherd, T. G., Reader, M. C., and Manney, G. L.: Dynamical control of the mesosphere by orographic and non-orographic gravity wave drag during the extended northern winters of 2006 and 2009, J. Atmos. Sci., 70, 2152-2161, 2013.

Medvedev, A. S. and Fomichev, V. I.: Net radiative heating and diagnostics of the diabatic circulation in the $15-110 \mathrm{~km}$ height layer, 56, 1574-1581, https://doi.org/10.1016/00219169(94)90087-6, 1994.

Meraner, K. and Schmidt, H.: Transport of nitrogen oxides through the winter mesopause in HAMMONIA, J. Geophys. Res.-Atmos., 121, 2556-2570, https://doi.org/10.1002/2015JD024136, 2016.

Meraner, K., Schmidt, H., Manzini, E., Funke, B., and Gardini A.: Sensitivity of simulated mesospheric transport of nitrogen oxides to parameterized gravity waves, J. Geophys. Res.-Atmos., 121, 12045-12061, https://doi.org/10.1002/2016JD025012, 2016.

Monier, E. and Weare, B. C.: Climatology and trends in the forcing of the stratospheric ozone transport, Atmos. Chem. Phys., 11, 6311-6323, https://doi.org/10.5194/acp-11-6311-2011, 2011.

Müller, R., Crutzen, P. J., Grooß, J.-U., Brühl, C., Russel III, J. M., and Tuck, A. F.: Chlorine activation and ozone depletion in the Arctic vortex: Observations by the Halogen Occultation Experi- 
ment on the Upper Atmosphere Research Satellite, J. Geophys. Res., 101, 12531-12554, 1996.

Müller, R., Tilmes, S., Grooß, J.-U, McKenna, D. S., Müller, M., Schmidt, U., Toon, G. C., Stachnik, R. A., Margitan, J. J., Elkins, J. W., Arvelius, J., and Russel III, J. M.: Chlorine activation and chemical ozone loss deduced from HALOE and balloon measurements in the Arctic during the winter of 1999-2000, J. Geophys. Res., 108, 8302, https://doi.org/10.1029/2001JD001423, 2003.

Nassar, R., Bernath, P. F., Boone, C. D., Manney, G. L., McLeod, S. D., Rinsland, C. P., Skelton, R., and Walker, K. A.: ACE-FTS measurements across the edge of the winter 2004 Arctic vortex, Geophys. Res. Lett., 32, L15S05, https://doi.org/10.1029/2005GL022671, 2005.

Neale, R., Richter, J., Park, S., Lauritzen, P., Vavrus, S., Rasch, P., and Zhang, M.: The mean climate of the Community Atmosphere Model (CAM4) in forced SST and fully coupled experiments, J. Climate, 26, 5150-5168, 2013.

Orsolini, Y. J., Urban, J., Murtagh, D., Lossow, S., and Lympasuvan, V.: Descent from the polar mesosphere and anomalously high stratopause observed in 8 years of water vapor and temperature satellite observations by the Odin submillimeter radiometer, J. Geophys. Res., 115, D12305, https://doi.org/10.1029/2009JD013501, 2010.

Pickett, H. M., Read, W. G., Lee, K. K., and Yung, Y. L.: Observation of night $\mathrm{OH}$ in the mesosphere, Geophys. Res. Lett., 33, L19808, https://doi.org/10.1029/2006GL026910, 2006.

Plumb, R. A., Heres W., Neu, J. L., Mahowald, N. M., del Corral, J., Toon, G. C., Ray, E., Moore, F., and Andrews, A. E.: Global tracer modeling during SOLVE: Highlatitude descent and mixing, J. Geophys. Res., 107, 8309, https://doi.org/10.1029/2001JD001023, 2002.

Proffitt, M. H., Margitan, J. J., Kelly, K. K., Loewenstein, M., Podolske, J. R., and Chan, K. R.: Ozone loss in the Arctic polar vortex inferred from high altitude aircraft measurements, Nature, 347, 31-36, 1990.

Proffitt, M. H., Aikin, K., Margitan, J. J., Loewenstein, M., Podolske, J. R., Weaver, A., Chan, K. R., Fast, H., and Elkins, J. W.: Ozone loss inside the northern polar vortex during the 19911992 winter, Science, 261, 1150-1154, 1993.

Pumphrey, H. C., Filipiak, M. J., Livesey, N. J., Schwartz, M. J., Boone, C., Walker, K. A., Bernath, P., Ricaud, P., Barret, B., Clerbaux, C., Jarnot, R. F., Manney, G. L., and Waters, J. W.: Validation of middle-atmosphere carbon monoxide retrievals from MLS on Aura, J. Geophys. Res., 112, D24S38, https://doi.org/10.1029/2007JD008723, 2007.

Raffalski, U., Berg, H., Hochschild, G., and Kopp, G.: Continuous ozone measurements over Kiruna during winter/spring 2002: A new millimeter wave radiometer operated at the Swedish Institute of Space Physics, Kiruna, Sweden, Proceedings of the Sixth European Symposium on Stratospheric Ozone Research, Gothenberg, Sweden, 369-372, 2002.

Randall, C. E., Harvey, V. L., Manney, G. L., Orsolini, Y., Codrescu, M., Sioris, C., Brohede, S., Haley, C. S., Gordley, L. L., Zawodny, J. M., and Russell, J. M.: Stratospheric effects of energetic particle precipitation in 2003-2004, Geophys. Res. Lett., 32, L05802, https://doi.org/10.1029/2004GL022003, 2005.

Randall, C. E., Harvey, V. L., Singleton, C. S., Bernath, P. F., Boone, C. D., and Kozyra, J. U.: Enhanced $\mathrm{NO}_{x}$ in 2006 linked to strong upper stratospheric Arctic vortex, Geophys. Res. Lett., 33, L18811, https://doi.org/10.1029/2006GL027160, 2006.

Randall, C. E., Harvey, V. L., Singleton, C., S., Bailey, S. M., Bernath, P. F., Codrescu, M., Nakajima, H., and Russell III, J. M.: Energetic particle precipitation effects on the southern hemisphere stratosphere in 1992-2005, J. Geophys. Res., 112, D08308, https://doi.org/10.1029/2006JD007696, 2007.

Randall, C. E., Harvey, V. L., Siskind, D. E., France, J., Bernath, P. F., Boone, C. D., and Walker, K. A.: $\mathrm{NO}_{x}$ descent in the Arctic middle atmosphere in early 2009, Geophys. Res. Lett., 36 , L18811, https://doi.org/10.1029/2009GL039706, 2009.

Randall, C. E., Harvey, V. L., Holt, L. A., Marsh, D. R., Kinnison, D., Funke, B., and Bernath P. F.: Simulation of energetic particle precipitation effects during the 20032004 Arctic winter, J. Geophys. Res.-Space, 120, 5035-5048, https://doi.org/10.1002/2015JA021196, 2015.

Rienecker, M. M, Suarez, M. J., Todling, R., Bacmeister, J., Takacs, L., Liu, H.-C., Gu, W., Sienkiewicz, M., Koster, R. D., Gelaro, R., Stajner, I., and Nielsen, J. E.: The GEOS-5 Data Assimilation System-Documentation of Versions 5.0.1, 5.1.0, and 5.2.0, Tech Rep. 104606 V27, NASA, Greenbelt, MD, 2008.

Rienecker, M. M., Suarez, M. J., Gelaro, R., Todling, R., Bacmeister, J., Liu, E., Bosilovich, M. G., Schubert, S. D., Takacs, L., Kim, G.-K., Bloom, S., Chen, J., Collins, D., Conaty, A., da Silva, A., Gu, W., Joiner, J., Koster, R. D., Lucchesi, R., Molod, A., Owens, T., Pawson, S., Pegion, P., Redder, C. R., Reichle, R., Robertson, F. R., Ruddick, A. G., Sienkiewicz, M., and Woollen, J.: MERRA: NASA's Modern-Era Retrospective Analysis for Research and Applications, J. Climate, 24, 3624-3648, https://doi.org/10.1175/JCLI-D-11-00015.1, 2011.

Rodgers, C. D. and Connor, B. J.: Intercomparison of remote sounding instruments, J. Geophys. Res., 108, 4116, https://doi.org/10.1029/2002JD002299, 2003.

Rösevall, J. D., Murtagh, D. P., and Urban, J.: Ozone depletion in the 2006/2007 Arctic winter, Geophys. Res. Lett., 34, L21809, https://doi.org/10.1029/2007GL030620, 2007.

Ryan, N. J., Palm, M., Raffalski, U., Larsson, R., Manney, G., Millán, L., and Notholt, J.: Strato-mesospheric carbon monoxide profiles above Kiruna, Sweden $\left(67.8^{\circ} \mathrm{N}, 20.4^{\circ} \mathrm{E}\right)$, since 2008 , Earth Syst. Sci. Data, 9, 77-89, https://doi.org/10.5194/essd-977-2017, 2017a.

Ryan, N. J., Palm, M., Raffalski, U., Larsson, R., Manney, G., Millán, L., Notholt, J.: Middle atmospheric carbon monoxide above Kiruna, Sweden $\left(67.8^{\circ} \mathrm{N}, 20.4^{\circ} \mathrm{E}\right), 2008-2015$, PANGAEA, https://doi.org/10.1594/PANGAEA.861730, 2017b.

Salawitch, R. J., Margitan, J. J., Sen, B., Toon, G. C., Osterman, G. B., Rex. M., Elkins, J. W., Ray, E. A., Moore, F. L., Hurst, D. F., Romashkin, P. A., Bevilacqua, R. M., Hoppel, K. W., Richard, E. C., and Bui, T. P.: Chemical loss of ozone during the Arctic winter of 1999/2000: An analysis based on balloon-borne observations, J. Geophys. Res., 107, 8269, https://doi.org/10.1029/2001JD000620, 2002.

Schoeberl, M. R., Lait, L. R., Newman, P. A., and Rosenfield, J. E.: The structure of the polar vortex, J. Geophys. Res., 97, 78597882, 1992.

Schwartz, M., Pumphrey, H., Livesey, N., and Read, W.: MLS/Aura Level 2 Carbon Monoxide (CO) Mixing Ratio V004, version 004, Greenbelt, MD, USA, Goddard Earth Sci- 
ences Data and Information Services Center (GES DISC), https://doi.org/10.5067/AURA/MLS/DATA2005, 2015.

Siskind, D. E., Eckermann, S. D., McCormack, J. P., Coy, L., Hoppel, K. W., and Baker, N. L.: Case studies of the mesospheric response to minor, major and extended stratospheric warmings, J. Geophys. Res., 115, D00N03, https://doi.org/10.1029/2010JD014114, 2010.

Siskind, D. E., Nedoluha, G. E., Sassi, F., Rong, P., Bailey, S. M., Hervig, M. E., and Randall, C. E.: Persistence of upper stratospheric wintertime tracer variability into the Arctic spring and summer, Atmos. Chem. Phys., 16, 7957-7967, https://doi.org/10.5194/acp-16-7957-2016, 2016.

Smith, A. K., Garcia, R. R., Marsh, D. R., and Richter J. H.: WACCM simulations of the mean circulation and trace species transport in the winter mesosphere, J. Geophys. Res., 116, D20115, https://doi.org/10.1029/2011JD016083, 2011.

Solomon, S., Garcia, R. R., Olivero, J. G., Bevilacqua, R. M., Schwarzt, P. R., Clancy, R. T., and Muhleman, D. O.: Photochemistry and Transport of Carbon Monoxide in the Middle Atmosphere, J. Atmos. Sci., 42, 1072-1083, 1985.

Solomon, S., Kiehl, J. T., Garcia, and Grose, W.: Tracer Transport by the Diabatic Circulation Deduced from Satellite Observations, J. Atmos. Sci., 43, 1603-1617, https://doi.org/10.1175/15200469(1986)043<1603:TTBTDC>2.0.CO;2, 1986.
Straub, C., Tschanz, B., Hocke, K., Kämpfer, N., and Smith, A. K.: Transport of mesospheric $\mathrm{H}_{2} \mathrm{O}$ during and after the stratospheric sudden warming of January 2010: observation and simulation, Atmos. Chem. Phys., 12, 5413-5427, https://doi.org/10.5194/acp-12-5413-2012, 2012.

Waters, J., Froidevaux, L., Harwood, R., Jarno, R., Pickett, H., Read, W., Siegel, P., Cofield, R., Filipiak, M., Flower, D., Holden, J., Lau, G., Livesey, N., Manney, G., Pumphrey, H., Santee, M., Wu, D., Cuddy, D., Lay, R., Loo, M., Perun, V., Schwartz, M., Stek, P., Thurstans, R., Boyles, M., Chandra, S., Chavez, M., Chen, G.-S., Chudasama, B., Dodge, R., Fuller, R., Girard, M., Jiang, J., Jiang, Y., Knosp, B., LaBelle, R., Lam, J., Lee, K., Miller, D., Oswald, J., Patel, N., Pukala, D., Quintero, O., Scaff, D., Snyder, W., Tope, M., Wagner, P., and Walch, M.: The Earth Observing System Microwave Limb Sounder (EOSMLS) on the Aura satellite, IEEE T. Geosci. Remote, 44, 1075-1092, 2006.

York, D., Evensen, N. M., Martinez, M. L., and Delgado, J. D. B.: Unified equations for the slope, intercept, and standard errors of the best straight line, Am. J. Phys., 72, 367-375, 2004. 